\title{
Removal Dynamics of Nitric Oxide (NO) Pollutant Gas by Pulse-Discharged Plasma Technique
}

\author{
Lianshui Zhang, Xiaojun Wang, Weidong Lai, Xueliang Cheng, and Kuifang Zhao \\ College of Physics Science and Technology, Hebei University, Baoding, Hebei Province 071002, China \\ Correspondence should be addressed to Xiaojun Wang; xiaojunwang1978@163.com
}

Received 4 November 2013; Accepted 18 January 2014; Published 5 March 2014

Academic Editors: A. Hursthouse and G. Sen

Copyright (C) 2014 Lianshui Zhang et al. This is an open access article distributed under the Creative Commons Attribution License, which permits unrestricted use, distribution, and reproduction in any medium, provided the original work is properly cited.

\begin{abstract}
Nonthermal plasma technique has drawn extensive attentions for removal of air pollutants such as $\mathrm{NO}_{x}$ and $\mathrm{SO}_{2}$. The $\mathrm{NO}$ removal mechanism in pulse discharged plasma is discussed in this paper. Emission spectra diagnosis indicates that the higher the discharge voltage is, the more the $\mathrm{NO}$ are removed and transformed into $\mathrm{O}, \mathrm{N}, \mathrm{N}_{2}, \mathrm{NO}_{2}$, and so forth. Plasma electron temperature $T_{e}$ is ranged from $6400 \mathrm{~K}$ at $2.4 \mathrm{kV}$ discharge voltage to $9500 \mathrm{~K}$ at $4.8 \mathrm{kV}$. After establishing a zero-dimensional chemical reaction kinetic model, the major reaction paths are clarified as the electron collision dissociation of $\mathrm{NO}$ into $\mathrm{N}$ and $\mathrm{O}$ during discharge and followed by single substitution of $\mathrm{N}$ on $\mathrm{NO}$ to form $\mathrm{N}_{2}$ during and after discharge, compared with the small fraction of $\mathrm{NO}_{2}$ formed by oxidizing NO. The reaction directions can be adjusted by $\mathrm{N}_{2}$ additive, and the optimal $\mathrm{N}_{2} / \mathrm{NO}$ mixing ratio is $2: 1$. Such a ratio not only compensates the disadvantage of electron competitive consumption by the mixed $\mathrm{N}_{2}$, but also heightens the total NO removal extent through accelerating the NO oxidization process.
\end{abstract}

\section{Introduction}

Nitrogen Oxides $\left(\mathrm{NO}_{x}\right)$, usually emitted through exhaust gas, have assumed the major responsibility with sulfur dioxide $\left(\mathrm{SO}_{2}\right)$ for acid rain formation, which is harmful to human health and to the environment through acid deposition [13]. High-efficient $\mathrm{NO}_{x}$ remediation or removal technologies has drawn extensive attentions for environmental protection from the viewpoint of fuel corporations, thermal power plants, explosive motor designers, and so on [4-7]. Catalysis reduction [8-11] or direct thermal decomposition $[12,13]$ approaches have been applied, but the reaction temperatures are usually high [14], which cannot directly be used for removing the $100-200^{\circ} \mathrm{C}$ diesel or power plant exhaust gas. One candidate way without high temperature control is the nonthermal plasma method at atmospheric pressure [15-17]. Such technique is typically consisting of an array of discharge filaments lasting for tens to hundreds of nanoseconds, in which high energy electrons are initiated by the high voltage and flowed into the exhaust gas. Electron collision can decompose the $\mathrm{NO}_{x}$ into other chemical species as atoms, ions, and molecules, restricted by the law of conservation of matter and the overall charge roughly of zero. Complicated physical-chemical reactions have occurred between the electrons, by-products, and the pollutant $\mathrm{NO}_{x}[18,19]$.

Various kinds of $\mathrm{NO}$ removal discharge techniques have been developed to date. One key factor that affects the removal efficiency is the appropriate gas components and discharge parameters. Leipold et al. plasma-treated exhaust gas by atmospheric pressure DBD (dielectric barrier discharges) and find that the $\mathrm{N}$ atoms have efficiently participated in the reaction of deoxidizing $\mathrm{NO}$ to $\mathrm{N}_{2}$ and $\mathrm{O}$ [27]. Wang et al. regard the hydroxyl $(\mathrm{OH})$, decomposed from $\mathrm{H}_{2} \mathrm{O}$, as the active radical to increase the oxidation efficiency of $\mathrm{NO}$ in $\mathrm{NO} / \mathrm{O}_{2} / \mathrm{N}_{2} / \mathrm{C}_{2} \mathrm{H}_{4}$ system. When too more vapor is mixed, the quenching effect on $\mathrm{NO}$ removal appears through the consumption on other active species by $\mathrm{H}_{2} \mathrm{O}$ [28]. Tsai et al. find that the elevated discharge power or decreased $\mathrm{O}_{2}$ concentration can improve the NO removal efficiency for the $\mathrm{NO} / \mathrm{N}_{2} / \mathrm{O}_{2}(2 \%) / \mathrm{H}_{2} \mathrm{O}(10 \%)$ mixtures [29]. To monitor the de- $\mathrm{NO}_{x}$ process, optical emission spectroscopy $[30,31]$ or laser induced fluorescence (LIF) [32] has been applied for contactless diagnosis of the radicals and by-products in plasma.

Another factor is the design of plasma reactor structure for improving energy consumption efficiency. Plasma 


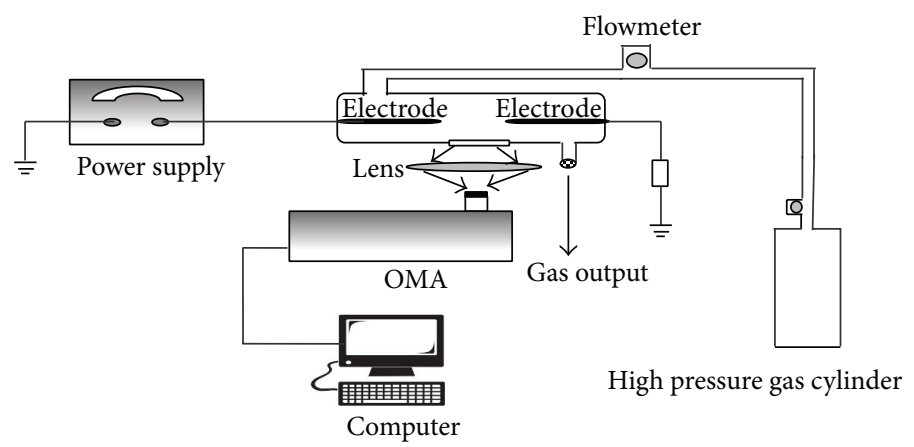

FIgURE 1: Schematic diagram of the pulse-discharged system for NO removal.

generated by radio-frequency (RF) electric field is reported to resonantly accumulate electromagnetic energy at low-voltage power supply, with $\mathrm{NO}$ efficiently oxidized to form $\mathrm{NO}_{2}$ in the plasma at atmospheric pressure [33]. Multirod DBD reactor is introduced for $\mathrm{NO}$ removal based on both dielectric barrier discharges and sliding discharges, and higher NO removal rate is yielded by pulse discharge in comparison with AC discharge at same energy density [34]. The influence of surface plasma reactions on $\mathrm{NO}_{x}$ removal has been recognized; surface- and volume-plasma are compared [35]. In order to remove NO from exhaust gas, investigations are also focused on the conversion of $\mathrm{NO}$ into $\mathrm{NO}_{2}$, which can be conveniently removed by chemical scrubbers such as sodium sulfite $\left(\mathrm{Na}_{2} \mathrm{SO}_{3}\right)$ solution [36].

In order to further promote the $\mathrm{NO}_{x}$ removal, plasma technique can be combined with catalysts. Combined adsorption-discharge plasma technique has been proposed, as $\mathrm{NO}_{x}$ firstly adsorbed on H-ZSM-5c substrate and then reduced by $\mathrm{CH}_{4}$ or $\mathrm{NH}_{3}$ in plasma $[37,38]$. Takahara et al. report that $\mathrm{Pt}$ catalyst can assist the discharged $\mathrm{NO}$ removal process with high activity under a humidified condition, in which $\mathrm{N}_{2} \mathrm{O}$ formed as intermediate species for promoting $\mathrm{N}_{2}$ formation [39]. Pulsed corona combined with $\mathrm{CaOH}_{2}$ absorption technique presents that $\mathrm{SO}_{2}$ and $\mathrm{NO}$ in the gas are oxidized into $\mathrm{SO}_{3}$ and $\mathrm{NO}_{2}$ by plasma and then absorbed by the $\mathrm{CaOH}_{2}$ [40]. Such combined processes have the advantages of operating in a wide range of temperatures.

Most of the researches pay attentions to the topic about how to achieve higher $\mathrm{NO}_{x}$ removal efficiency with lower energy cost for practical demand. But the practicability has been restricted by the poor comprehensions of dynamic mechanism of NO removal due to the complicated reactions in plasma. Accurate measurements of the nitrogen oxides and other by-products under different conditions are usually difficult. It is necessary to clarify the NO removal process in order to optimize the operating conditions such as the applied voltage and the additive gas.

In this paper, the pulse discharged plasma for NO remediation has been experimentally achieved and theoretically simulated. Emission spectra are diagnosed to discriminate the category of by-products and supervise the NO removal process. The relationship between discharge voltage and plasma electron temperatures $T_{\mathrm{e}}$ is discussed to evaluate the chemical activity of NO removal reactions from macroscopic viewpoint. Since the microcosmic dynamic process is difficult to be experimentally obtained, a chemical kinetic model is developed in this paper. Generating and losing reactions of different main species in the plasma have been analyzed. The effects of pulse discharge duration width and additive gas on NO removal efficiency are focused on. It finds that pulse-discharged plasma technique assisted with $\mathrm{N}_{2}$ additive can efficiently remove the gas pollutant of $\mathrm{NO}$ and has the potential utilization in power plants, automobiles, and so on.

\section{Experimental Methods}

The experimental instrument is schematically present in Figure 1. Two tungsten pointing electrodes of $1 \mathrm{~mm}$ in diameter are oppositely placed to act as discharge system, with the separation distance of $3 \mathrm{~mm}$. The two electrodes are powered by high voltage pulse source, which can be adjusted in the range from 1 to $15 \mathrm{kV}$. The pulse duration is $24.5 \mathrm{~ns}$, with discharge frequency of $50 \mathrm{~Hz}$. Discharge process between the electrodes is operated in a glass reactor with diameter of $25 \mathrm{~mm}$ and volumetric capacity of $40 \mathrm{~mL}$. Gases with purity of $99.99 \%$ are delivered into the discharge zone after flowing through the connected pipes. The air pressure in the reactor is manipulated by vacuum pump and gas flowmeter and controlled at $0.2 \mathrm{~atm}$.

Emission spectra are collected through a quartz window, with diameter of $18 \mathrm{~mm}$ on the glass reactor wall corresponding to the discharge zone. The spectra are then detected by OMA (Optical Multichannel Analyzer, ACTON, SP-2300) with the spectra detecting resolution of $0.1 \mathrm{~nm}$.

\section{Results and Discussion}

There are two critical factors in practical application for discharge removing pollutant gas: (1) electrical energy consumption and (2) by-product identification. Here, the former is evaluated as plasma electron temperature $T_{\mathrm{e}}$ based on Boltzmann distribution theory; the latter is obtained based on the emission spectra diagnostic technique.

3.1. Emission Spectra Diagnostics of NO. The NO emission spectra have been detected and shown in Figure 2(a). A notable sequence of UV radiation has been produced, which 


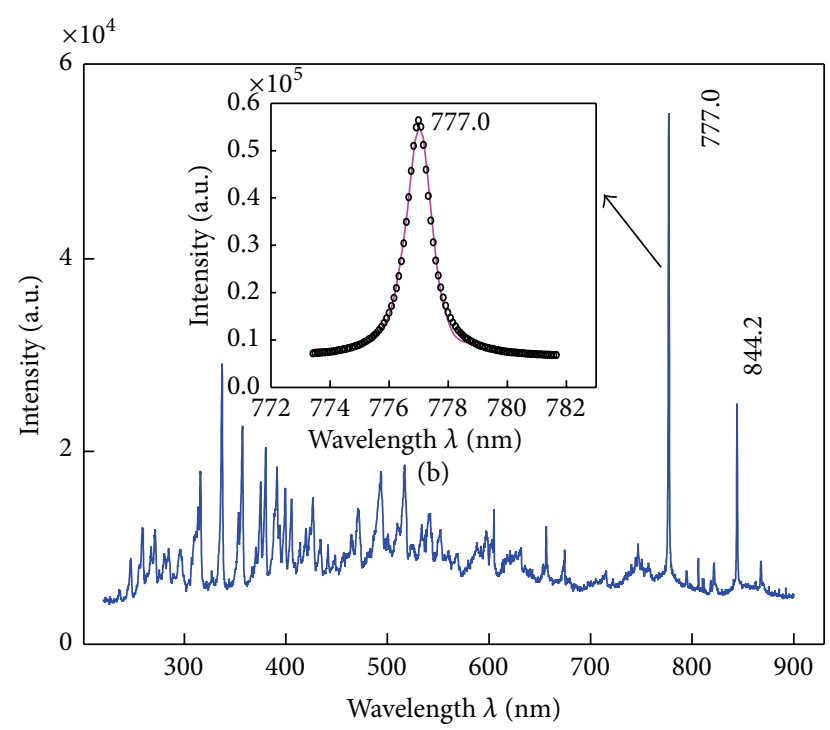

(a)

FIGURE 2: (a) Emission spectra detected from the pulse discharged instrument; (b) Lorentz fitting for the emission spectra of $\mathrm{O}$ atoms at $777.0 \mathrm{~nm}$.

belongs to $\mathrm{NO}$ and new species of $\mathrm{N}_{2}$ molecules as well as $\mathrm{N}_{2}^{+}$ion. From $493 \mathrm{~nm}$, spectra of another new species $\mathrm{NO}_{2}$ appear. In the wavelength range from $656 \mathrm{~nm}$ to $867 \mathrm{~nm}$, the atom or ion species of $\mathrm{N}, \mathrm{O}, \mathrm{N}^{+}$have played the essential roles. The atom spectra of $\mathrm{N}$ and $\mathrm{O}$ have only instrument broadening and can be well fitted by Lorentz function, which has been shown in Figure 2(b) with $\mathrm{O}$ atom at $777.0 \mathrm{~nm}$ as an example.

Apart from those lines of the NO, the most important feature of the emission diagnostics is that new species of $\mathrm{N}$, $\mathrm{N}_{2}, \mathrm{~N}^{+}, \mathrm{N}_{2}^{+}$, and $\mathrm{O}$ as well as $\mathrm{NO}_{2}$ appeared. $\mathrm{O}_{2}$ molecules are also formed, though no distinct emission lines detected, due to its very low transition probability for radiation. It implies that some extent of NO has been transformed into new species, including harmless species such as $\mathrm{N}, \mathrm{O}, \mathrm{N}_{2}, \mathrm{O}_{2}$, $\mathrm{N}^{+}$, and $\mathrm{N}_{2}{ }^{+}$, or can be further removed by other methods such as $\mathrm{NO}_{2}$.

The emission spectra and their transition channels are evaluated [41] and outlined in Table 1.

Based on the species diagnostic details in Table 1, the main reaction paths and chemical species with comparatively large reaction magnitude order are estimated as follows (Figure 3). During discharge between the two electrodes, elastic collision and inelastic collision between the injected electrons and NO molecules have initiated the electronimpact dissociation of $\mathrm{NO}$, followed by other subsequent reactions to form $\mathrm{NO}^{+}, \mathrm{N}, \mathrm{N}_{2}, \mathrm{~N}_{2}{ }^{+}, \mathrm{N}^{+}, \mathrm{O}$, and $\mathrm{O}_{2}$ as well as $\mathrm{NO}_{2}$.

Though $\mathrm{NO}_{2}$ is generated as another kind of nitrogen oxides which is also harmful, the $\mathrm{NO}_{2}$ can be conveniently reduced using sulfite solution based on the reaction as $2 \mathrm{NO}_{2}$ $+4 \mathrm{SO}_{3}{ }^{-2} \rightarrow 4 \mathrm{SO}_{4}{ }^{-2}+\mathrm{N}_{2}$ [42]. $\mathrm{NO}_{2}$ generation is usually accepted to be effective for $\mathrm{NO}$ removal.
TABLE 1: Emission spectra and transition channel diagnosed from the NO emission lines.

\begin{tabular}{|c|c|c|}
\hline$\lambda / \mathrm{nm}$ & Transition channel & Species \\
\hline 236.1 & $\mathrm{~A}^{2} \sum \rightarrow \mathrm{X}^{2} \prod(0-1)$ & NO \\
\hline 247.3 & $\mathrm{~A}^{2} \sum \rightarrow \mathrm{X}^{2} \prod(0-2)$ & NO \\
\hline 258.9 & $\mathrm{~A}^{2} \sum \rightarrow \mathrm{X}^{2} \prod(0-3)$ & NO \\
\hline 271.4 & $\mathrm{~A}^{2} \sum \rightarrow \mathrm{X}^{2} \prod(0-4)$ & NO \\
\hline 280.0 & $\mathrm{~A}^{2} \sum \rightarrow \mathrm{X}^{2} \prod(1-6)$ & NO \\
\hline 295.2 & $\mathrm{~A}^{2} \sum \rightarrow \mathrm{X}^{2} \prod(1-7)$ & NO \\
\hline 315.8 & $\mathrm{C}^{3} \prod_{u} \rightarrow \mathrm{B}^{3} \prod_{g}(1-0)$ & $\mathrm{N}_{2}$ \\
\hline 337.2 & $\mathrm{C}^{3} \prod_{u} \rightarrow \mathrm{B}^{3} \prod_{g}(0-0)$ & $\mathrm{N}_{2}$ \\
\hline 357.3 & $\mathrm{C}^{3} \prod_{u} \rightarrow \mathrm{B}^{3} \prod_{g}(0-1)$ & $\mathrm{N}_{2}$ \\
\hline 375.1 & $\mathrm{C}^{3} \prod_{u} \rightarrow \mathrm{B}^{3} \prod_{g}(1-3)$ & $\mathrm{N}_{2}$ \\
\hline 380.0 & $\mathrm{C}^{3} \prod_{u} \rightarrow \mathrm{B}^{3} \prod_{g}(0-2)$ & $\mathrm{N}_{2}$ \\
\hline 391.2 & $\mathrm{~B}^{2} \sum_{u}^{+} \rightarrow \mathrm{X}^{2} \sum_{g}^{+}(0-0)$ & $\mathrm{N}_{2}^{+}$ \\
\hline 399.5 & $\mathrm{C}^{3} \prod_{u} \rightarrow \mathrm{B}^{3} \prod_{g}(1-4)$ & $\mathrm{N}_{2}$ \\
\hline 405.6 & $\mathrm{C}^{3} \prod_{u} \rightarrow \mathrm{B}^{3} \prod_{g}(0-3)$ & $\mathrm{N}_{2}$ \\
\hline 426.5 & $\mathrm{~B}^{2} \sum_{u}^{+} \rightarrow \mathrm{X}^{2} \sum_{g}^{+}(0-1)$ & $\mathrm{N}_{2}^{+}$ \\
\hline 434.0 & $\mathrm{C}^{3} \prod_{u} \rightarrow \mathrm{B}^{3} \prod_{g}(0-4)$ & $\mathrm{N}_{2}$ \\
\hline 441.4 & $\mathrm{C}^{3} \prod_{u} \rightarrow \mathrm{B}^{3} \prod_{g}(3-8)$ & $\mathrm{N}_{2}$ \\
\hline 464.5 & $\mathrm{~B}^{2} \sum_{u}^{+} \rightarrow \mathrm{X}^{2} \sum_{g}^{+}{ }^{+}(1-3)$ & $\mathrm{N}_{2}^{+}$ \\
\hline 470.7 & $\mathrm{~B}^{2} \sum_{u}^{+} \rightarrow \mathrm{X}^{2} \sum_{g}^{+}(0-2)$ & $\mathrm{N}_{2}^{+}$ \\
\hline 493.4 & $\mathrm{~A}^{2} \mathrm{~B}_{1} \rightarrow \mathrm{X}^{2} \mathrm{~A}_{1}(1,5,0-0,0,0)$ & $\mathrm{NO}_{2}$ \\
\hline 516.8 & $\mathrm{~A}^{2} \mathrm{~B}_{1} \rightarrow \mathrm{X}^{2} \mathrm{~A}_{1}(1,4,0-0,0,0)$ & $\mathrm{NO}_{2}$ \\
\hline 540.4 & $\mathrm{~A}^{2} \mathrm{~B}_{1} \rightarrow \mathrm{X}^{2} \mathrm{~A}_{1}(1,3,0-0,0,0)$ & $\mathrm{NO}_{2}$ \\
\hline 552.3 & $\mathrm{~A}^{2} \mathrm{~B}_{1} \rightarrow \mathrm{X}^{2} \mathrm{~A}_{1}(3,0,0-0,0,0)$ & $\mathrm{NO}_{2}$ \\
\hline 568.0 & $\mathrm{~A}^{2} \mathrm{~B}_{1} \rightarrow \mathrm{X}^{2} \mathrm{~A}_{1}(1,2,0-0,0,0)$ & $\mathrm{NO}_{2}$ \\
\hline 5884 & $\mathrm{~A}^{2} \mathrm{~B}_{1} \rightarrow \mathrm{X}^{2} \mathrm{~A}_{1}(2,0,0-0,0,0)$ & $\mathrm{NO}_{2}$ \\
\hline 597.3 & $\mathrm{~A}^{2} \mathrm{~B}_{1} \rightarrow \mathrm{X}^{2} \mathrm{~A}_{1}(1,1,0-0,0,0)$ & $\mathrm{NO}_{2}$ \\
\hline 602.2 & $\mathrm{~A}^{2} \mathrm{~B}_{1} \rightarrow \mathrm{X}^{2} \mathrm{~A}_{1}(0,0,1-0,0,0)$ & $\mathrm{NO}_{2}$ \\
\hline 656.4 & $2 s 2 p^{2}\left({ }^{4} \mathrm{P}\right) 3 s \rightarrow 2 s^{2} 2 p 4 s$ & $\mathrm{~N}^{+}$ \\
\hline 674.6 & $2 s^{2} 2 p^{2}\left({ }^{3} \mathrm{P}\right) 4 d \rightarrow 2 s^{2} 2 p^{2}\left({ }^{3} \mathrm{P}\right) 3 p$ & $\mathrm{~N}$ \\
\hline 715.5 & $2 s 2 p^{2}\left({ }^{4} \mathrm{P}\right) 3 s \rightarrow 2 s^{2} 2 p 4 s$ & $\mathrm{~N}^{+}$ \\
\hline 746.8 & $2 s^{2} 2 p^{2}\left({ }^{3} \mathrm{P}\right) 3 p \rightarrow 2 s^{2} 2 p^{2}\left({ }^{3} \mathrm{P}\right) 3 s$ & $\mathrm{~N}$ \\
\hline 777.0 & $2 s^{2} 2 p^{3}\left({ }^{4} s^{\circ}\right) 3 p \rightarrow 2 s^{2} 2 p^{3}\left({ }^{4} s^{\circ}\right) 3 s$ & $\mathrm{O}$ \\
\hline 821.5 & $2 s^{2} 2 p^{2}\left({ }^{3} \mathrm{P}\right) 3 p \rightarrow 2 s^{2} 2 p^{2}\left({ }^{3} \mathrm{P}\right) 3 s$ & $\mathrm{~N}$ \\
\hline 844.2 & $2 s^{2} 2 p^{3}\left({ }^{4} S^{\circ}\right) 3 p \rightarrow 2 s^{2} 2 p^{3}\left({ }^{4} S^{\circ}\right) 3 s$ & $\mathrm{O}$ \\
\hline 867.6 & $2 s^{2} 2 p 5 s \rightarrow 2 s^{2} 2 p 4 p$ & $\mathrm{~N}^{+}$ \\
\hline
\end{tabular}

The electrical energy consumption for achieving desirable NO removal efficiency is of critical importance in practice. Under different discharge voltage from 2.4 to $4.8 \mathrm{kV}$, the emission spectra are shown in Figure 4.

By high voltage loaded, the emission spectra lines are located at the almost unchanged wavelength. Differently, the emission intensity has varied.

In order to clarify the influence of discharge energy, the characteristic spectra are selected at 337.2, 516.8, 777.0, and 
TABLE 2: Spectra constants of $\mathrm{O}$ atoms at 777.0 and $844.2 \mathrm{~nm}$ [20].

\begin{tabular}{lcc}
\hline$E_{k} / \mathrm{eV}$ & $\lambda_{k} / \mathrm{nm}$ & $A_{k} \times g_{k} / \mathrm{s}^{-1}$ \\
\hline 10.740931 & 777.0 & $2.58 \times 10^{8}$ \\
10.988861 & 844.2 & $1.61 \times 10^{8}$ \\
\hline
\end{tabular}

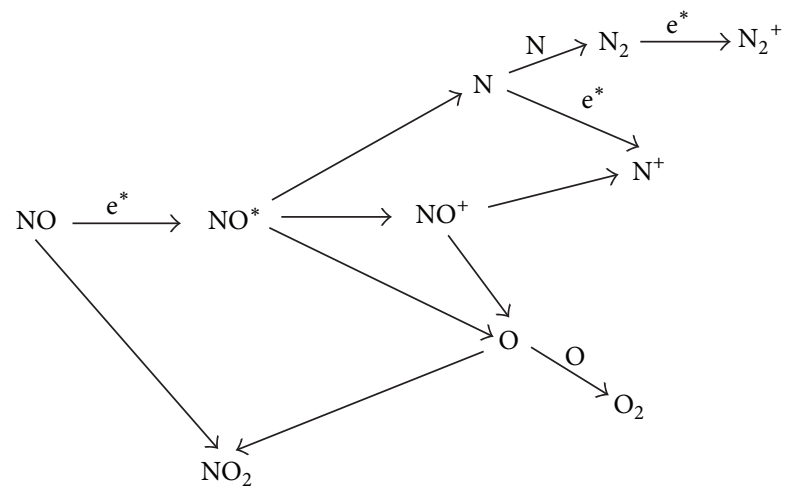

Figure 3: Diagram of main reaction paths and species during discharge.

$844.2 \mathrm{~nm}$ for $\mathrm{N}_{2}, \mathrm{NO}_{2}$, and $\mathrm{O}$, respectively. Figure 5 shows the emission intensity variance under different inputting voltages. With input energy increasing, the emission intensity of the new species $\mathrm{N}_{2}, \mathrm{NO}_{2}$, and $\mathrm{O}$ all have increased.

According to Einstein spontaneous emission law in (1) [43], the species concentration $n_{k, Z}$ is proportional to the emission intensity $I_{k i, Z}$ as follows:

$$
I_{k i, Z}=\frac{1}{4 \pi} \frac{h c}{\lambda_{k i, Z}} n_{k, Z} A_{k i, Z} l .
$$

In (1), $A_{k i}$ is the transition probability from energy level $k$ to level $i$ and $\lambda_{k i}$ is the corresponding emission wavelength. $l$ is the total plasma thickness. $h$ is the Planck's constant and $c$ is the light velocity in vacuum. $n_{k, Z}$ is the population in energy level $k$ of the species.

Based on (1) and Figure 5, a qualitative conclusion can be made that the higher input energy has heightened NO removal efficiency to generate more new species of $\mathrm{N}_{2}, \mathrm{NO}_{2}$, $\mathrm{O}$, and so forth.

In order to evaluate the plasma variance at different inputting energy, the plasma electron temperature $T_{\mathrm{e}}$ is analyzed according to the Boltzmann distribution law [44] under Local Thermodynamic Equilibrium (LTE) approximation as follows:

$$
\frac{n_{k, Z}}{n_{Z}}=\frac{g_{k, Z}}{P_{Z}} \exp \left[-\frac{E_{k, Z}}{k_{B} T_{\mathrm{e}}}\right] .
$$

In (2), $k_{B}$ is the Boltzmann's constant. $P_{Z}$ is related to the neutral or singly ionized atom state. $n_{Z}$ is the total population density. $g_{k, Z}$ and $E_{k, Z}$ are the degeneracy and energy of the level $k$.

Since the emission intensity is detected with arbitrary unit, the electron temperature $T_{\mathrm{e}}$ is impossible to be directly calculated. In order to obtain the $T_{\mathrm{e}}$, it is deduced from the

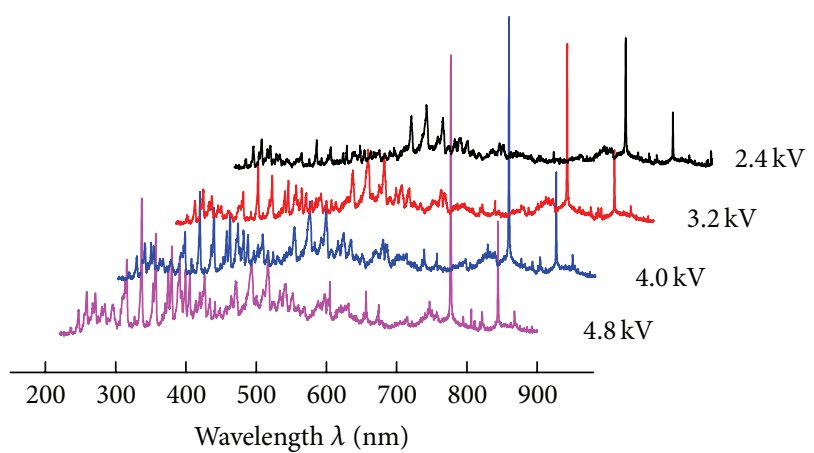

FIGURE 4: Emission spectra under different pulse voltage inputted from 2.4 to $4.8 \mathrm{kV}$.

ratio of two emission lines of the same atoms with same ionization stage $Z$, which is applied based on (1) and (2) as

$$
\begin{aligned}
& \frac{I_{1}}{I_{2}}=\frac{A_{1} g_{1} / \lambda_{1}}{A_{2} g_{2} / \lambda_{2}} \exp \left(-\frac{E_{1}-E_{2}}{k_{B} T_{\mathrm{e}}}\right) \\
& \text { or } T_{\mathrm{e}}=-\frac{E_{1}-E_{2}}{k_{B}\left(\ln \left(I_{1} A_{2} g_{2} \lambda_{1}\right)-\ln \left(I_{2} A_{1} g_{1} \lambda_{2}\right)\right)} .
\end{aligned}
$$

Such procedure has eliminated the disturbance of arbitrary unit. The characteristic emission has been selected as the two $\mathrm{O}$ atom lines at 777.0 and $844.2 \mathrm{~nm}$, due to their high signal-to-noise ratio. The emission constants are shown in Table 2.

Plot of $T_{\mathrm{e}}$ versus the inputted voltage yields Figure 6 . The obtained plasma electron temperature $T_{\mathrm{e}}$ is increasing with the voltage heightened. The $4.8 \mathrm{kV}$ discharge has achieved higher $T_{\mathrm{e}}$ of about $9500 \mathrm{~K}$, compared with that of $6403 \mathrm{~K}$ at $2.4 \mathrm{kV}$. Such $T_{\mathrm{e}}$ implies that the chemical reaction activation of the species in plasma is heightening for the NO removal.

It also should be noticed that NO transforming and removing process is difficult to be thoroughly detected by experimental methods, due to the complicated reactions in the plasma as shown in Figure 3. There has been a necessity to establish simulation model for analyzing the reaction dynamic.

3.2. Dynamic Simulation of NO Removal Process. To investigate the NO removal dynamic during and after discharge, the concentration variance of the $i$ th species is modeled as a time varying differential equation [45], which includes the generating and losing reaction paths of this given $i$ th species as in

$$
\frac{d n_{i}}{d t}=-\sum_{i, j} k_{i j} n_{i} n_{j}+\sum_{p, q} k_{p q} n_{p} n_{q}
$$

where, $n_{i}, n_{j}, n_{p}$ and $n_{q}$ are concentrations of the respective species and $k_{i j}$ and $k_{p q}$ are reaction rate coefficients of the losing and generating routines. Concentration loss of the $i$ th specie has occurred in the reaction between species $i$ and $j$, while specie $i$ generation is determined by the reaction between species $p$ and $q$. 


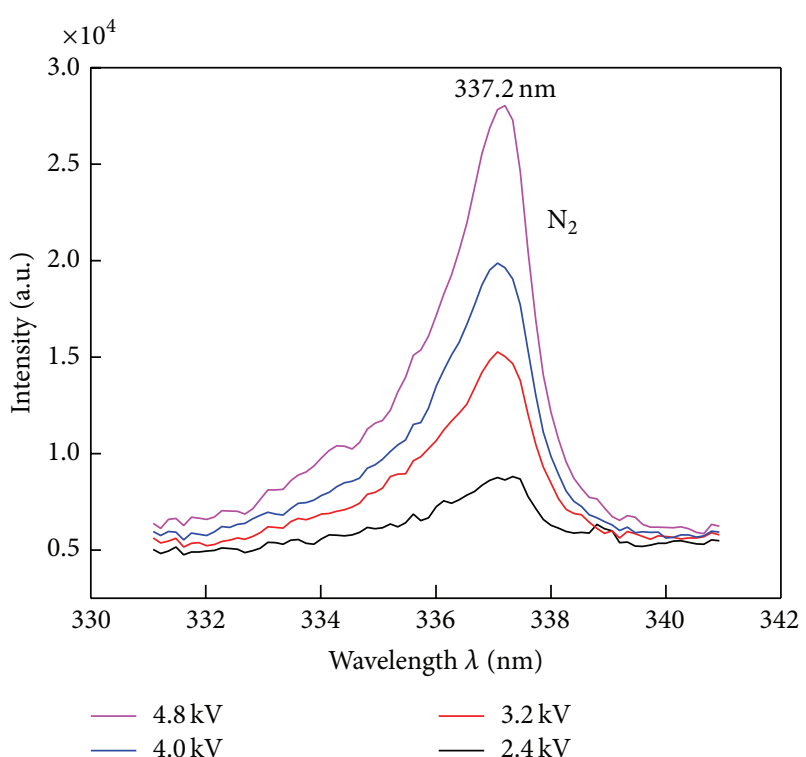

(a)

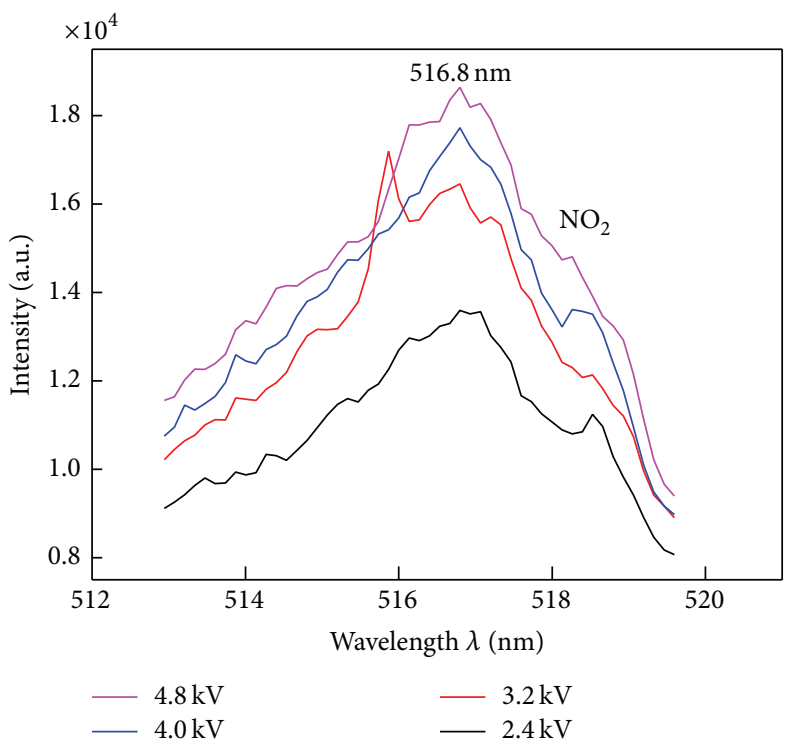

(b)

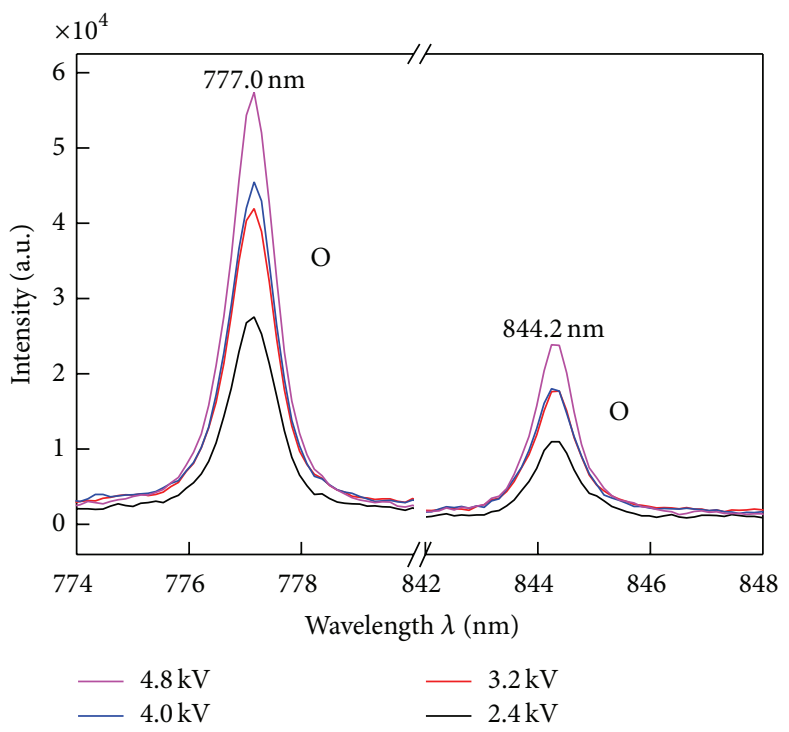

(c)

FiguRE 5: The characteristic spectra under different pulse voltage, identified at (a) $337.2 \mathrm{~nm}$ of $\mathrm{N}_{2}$ molecule, (b) $516.8 \mathrm{~nm}$ of $\mathrm{NO}_{2}$ molecule, and (c) $777.0 \mathrm{~nm}$ and $844.2 \mathrm{~nm}$ of $\mathrm{O}$ atom.

With spatial homogeneity hypothesis of the discharge, the plasma is simulated in zero-dimensional scale. Space diffusion of electrons, NO, and other by-products has been neglected, and the concentration of electrons and gas molecules in the whole volume of the plasma are assumed to be uniform. The reaction paths and corresponding kinetic rate coefficients $k$ are outlined in Table 3. For the electronexcited dissociation process, the rate constant $k$ can be calculated by

$$
k=\left(\frac{2}{m_{\mathrm{e}}}\right)^{1 / 2} \int_{0}^{\infty} E^{1 / 2} \sigma\left(E_{\mathrm{e}}\right) f\left(E_{\mathrm{e}}\right) d E_{\mathrm{e}} .
$$

In which, $E_{\mathrm{e}}$ and $m_{\mathrm{e}}$ are the electron energy and mass. $f\left(E_{\mathrm{e}}\right)$ is the electron distribution function, and $\sigma\left(E_{\mathrm{e}}\right)$ is the corresponding collision cross section [46].

The species' reactions are modeled as discrete timevarying stiff differential equation system and have been solved by Runge-Kutta algorithm [47].

NO concentration variance is shown in Figure 7, in which the concentration variance of electrons is also present. During pulse discharge, the concentration of NO is monotonically decreased. There was obvious NO removal effect, and about $5.5289 \% \mathrm{NO}$ has been transformed into other species during discharge that lasted for $24.5 \mathrm{~ns}$. After discharge, the electron concentration was assumed to be zero, whereas the NO 


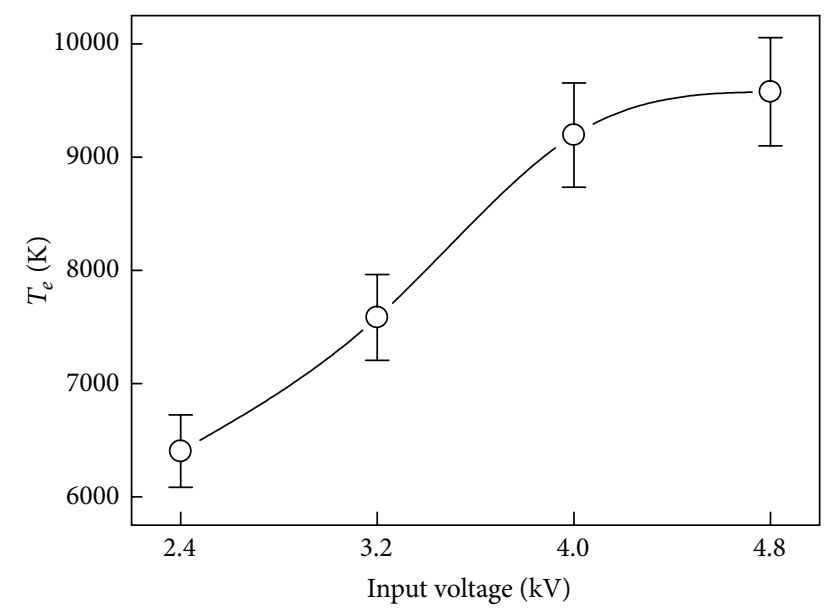

Figure 6: Plasma electron temperature $T_{\mathrm{e}}$ variance versus inputted voltage.

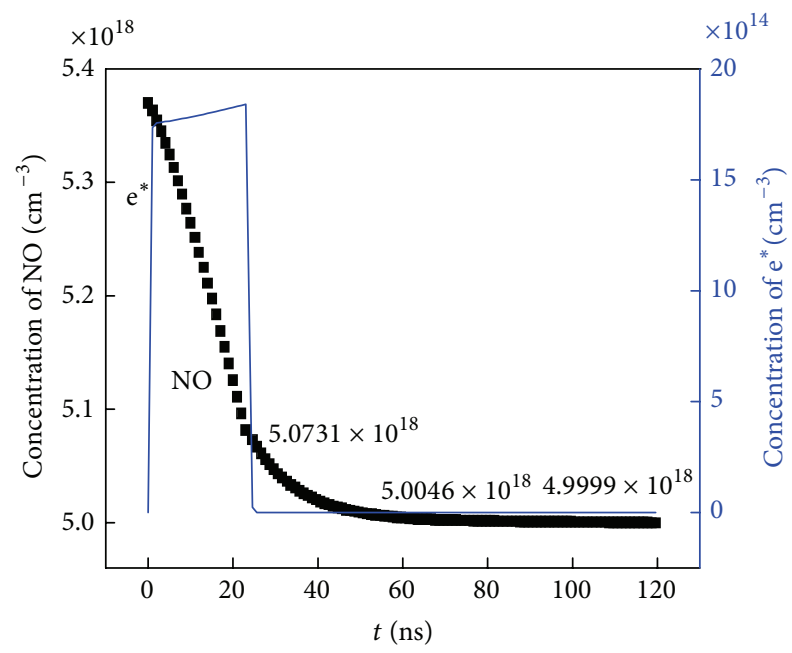

FIGURE 7: Concentration variance of NO molecules and electrons versus time. The concentration of NO is $5.37 \times 10^{18} / \mathrm{cm}^{3}$ at $0 \mathrm{~ns}$, $5.0731 \times 10^{18} / \mathrm{cm}^{3}$ at $24.5 \mathrm{~ns}, 5.0046 \times 10^{18} / \mathrm{cm}^{3}$ at $60 \mathrm{~ns}$, and 4.9999 $\times 10^{18} / \mathrm{cm}^{3}$ at $120 \mathrm{~ns}$.

concentration is also decreasing, and achieving 6.8045\% NO removal efficiency after $60 \mathrm{~ns}$ as well as $6.8920 \%$ after 120 ns.

From the viewpoint of main reaction paths for $\mathrm{NO}$ removal, the collision dissociation reaction by electrons on NO molecules during discharge is occupied the major position, and determined the most part of the NO removal percentage. On the contrary, the by-product species and radicals are playing important role after discharge and contribute to a small part of the NO removal percentage.

In order to clarify the effect of by-products on $\mathrm{NO}$ removal efficiency after discharge, the generating and losing dynamic process of $\mathrm{O}\left({ }^{3} \mathrm{P}\right), \mathrm{N}_{2}, \mathrm{NO}_{2}, \mathrm{O}_{2}, \mathrm{~N}, \mathrm{~N}\left({ }^{2} \mathrm{D}\right), \mathrm{N}_{2}{ }^{+}$, $\mathrm{N}^{+}$, and $\mathrm{O}\left({ }^{1} \mathrm{D}\right)$ are shown in Figure 8. During discharge, concentrations of all the by-product species are increasing. When discharge is completed, some species such as $\mathrm{N}$, $\mathrm{N}\left({ }^{2} \mathrm{D}\right), \mathrm{N}_{2}{ }^{+}, \mathrm{N}^{+}$, and $\mathrm{O}\left({ }^{1} \mathrm{D}\right)$ are consumed as shown in
TABLE 3: Reaction paths and the corresponding reaction rate coefficients [21-26].

\begin{tabular}{|c|c|}
\hline Reaction path & $k / \mathrm{cm}^{3} \mathrm{~s}^{-1}$ \\
\hline $\mathrm{e}^{*}+\mathrm{N}_{2} \rightarrow \mathrm{N}_{2}^{+}+2 \mathrm{e}$ & $2.4 \times 10^{-12}$ \\
\hline $\mathrm{e}^{*}+\mathrm{N}_{2} \rightarrow \mathrm{N}+\mathrm{N}+\mathrm{e}$ & $2.0 \times 10^{-11}$ \\
\hline $\mathrm{e}^{*}+\mathrm{NO} \rightarrow \mathrm{N}+\mathrm{O}\left({ }^{3} \mathrm{P}\right)+\mathrm{e}$ & $8.5 \times 10^{-10}$ \\
\hline $\mathrm{e}^{*}+\mathrm{NO} \rightarrow \mathrm{NO}^{+}+2 \mathrm{e}$ & $1.1 \times 10^{-10}$ \\
\hline $\mathrm{e}^{*}+\mathrm{NO}^{+} \rightarrow \mathrm{N}+\mathrm{O}\left({ }^{3} \mathrm{P}\right)$ & $8.2 \times 10^{-9}$ \\
\hline $\mathrm{e}^{*}+\mathrm{N}_{2}^{+} \rightarrow \mathrm{N}_{2}$ & $4.0 \times 10^{-12}$ \\
\hline $\mathrm{e}^{*}+\mathrm{NO}^{+} \rightarrow \mathrm{O}\left({ }^{3} \mathrm{P}\right)+\mathrm{N}\left({ }^{2} \mathrm{D}\right)$ & $4.3 \times 10^{-7}$ \\
\hline $\mathrm{N}^{+}+\mathrm{NO} \rightarrow \mathrm{N}_{2}^{+}+\mathrm{O}\left({ }^{3} \mathrm{P}\right)$ & $5.0 \times 10^{-11}$ \\
\hline $\mathrm{N}^{+}+\mathrm{O}_{2} \rightarrow \mathrm{NO}^{+}+\mathrm{O}\left({ }^{3} \mathrm{P}\right)$ & $2.6 \times 10^{-10}$ \\
\hline $\mathrm{N}_{2}^{+}+\mathrm{N} \rightarrow \mathrm{N}^{+}+\mathrm{N}_{2}$ & $1.0 \times 10^{-11}$ \\
\hline $\mathrm{N}_{2}^{+}+\mathrm{O}\left({ }^{3} \mathrm{P}\right) \rightarrow \mathrm{NO}^{+}+\mathrm{N}$ & $1.4 \times 10^{-10}$ \\
\hline $\mathrm{N}+\mathrm{NO}_{2} \rightarrow \mathrm{N}_{2}+\mathrm{O}\left({ }^{3} \mathrm{P}\right)+\mathrm{O}\left({ }^{3} \mathrm{P}\right)$ & $9.1 \times 10^{-13 *}$ \\
\hline $\mathrm{O}\left({ }^{3} \mathrm{P}\right)+\mathrm{NO}+\mathrm{N}_{2} \rightarrow \mathrm{NO}_{2}+\mathrm{N}_{2}$ & $1.0 \times 10^{-31}$ \\
\hline $\mathrm{N}_{2}(\mathrm{~A})+\mathrm{O}_{2} \rightarrow \mathrm{N}_{2}+\mathrm{O}\left({ }^{3} \mathrm{P}\right)+\mathrm{O}\left({ }^{3} \mathrm{P}\right)$ & $2.54 \times 10^{-12}$ \\
\hline $\mathrm{N}_{2}(\mathrm{~A})+\mathrm{NO} \rightarrow \mathrm{NO}+\mathrm{N}_{2}$ & $7.0 \times 10^{-11}$ \\
\hline $\mathrm{N}_{2}(\mathrm{~A})+\mathrm{N}_{2} \rightarrow \mathrm{N}_{2}+\mathrm{N}_{2}$ & $3.0 \times 10^{-18}$ \\
\hline $\mathrm{N}_{2}(\mathrm{~A})+\mathrm{NO}_{2} \rightarrow \mathrm{NO}+\mathrm{O}\left({ }^{3} \mathrm{P}\right)+\mathrm{N}_{2}$ & $1.0 \times 10^{-12}$ \\
\hline $\mathrm{NO}_{2}+\mathrm{O}\left({ }^{3} \mathrm{P}\right) \rightarrow \mathrm{NO}+\mathrm{O}_{2}$ & $9.1 \times 10^{-12}$ \\
\hline $\mathrm{O}\left({ }^{3} \mathrm{P}\right)+\mathrm{O}\left({ }^{3} \mathrm{P}\right)+\mathrm{O}_{2} \rightarrow \mathrm{O}_{2}+\mathrm{O}_{2}$ & $6.7 \times 10^{-33^{*}}$ \\
\hline $\mathrm{N}_{2}(\mathrm{~B})+\mathrm{O}_{2} \rightarrow \mathrm{N}_{2}(\mathrm{~A})+\mathrm{O}_{2}$ & $3.0 \times 10^{-10}$ \\
\hline $\mathrm{N}\left({ }^{2} \mathrm{D}\right)+\mathrm{O}_{2} \rightarrow \mathrm{NO}+\mathrm{O}\left({ }^{1} \mathrm{D}\right)$ & $6.0 \times 10^{-12}$ \\
\hline $\mathrm{N}\left({ }^{2} \mathrm{D}\right)+\mathrm{NO} \rightarrow \mathrm{N}_{2}+\mathrm{O}\left({ }^{3} \mathrm{P}\right)$ & $4.5 \times 10^{-11}$ \\
\hline $\mathrm{O}\left({ }^{1} \mathrm{D}\right)+\mathrm{NO} \rightarrow \mathrm{N}+\mathrm{O}_{2}$ & $8.5 \times 10^{-11}$ \\
\hline $\mathrm{e}^{*}+\mathrm{N}_{2} \rightarrow \mathrm{N}^{+}+\mathrm{N}+2 \mathrm{e}$ & $2.4 \times 10^{-17}$ \\
\hline $\mathrm{e}^{*}+\mathrm{N}_{2} \rightarrow \mathrm{N}_{2}(\mathrm{~A})+\mathrm{e}$ & $1.1 \times 10^{-10}$ \\
\hline $\mathrm{e}^{*}+\mathrm{N} \rightarrow \mathrm{N}^{+}+2 \mathrm{e}$ & $1.1 \times 10^{-10}$ \\
\hline $\mathrm{e}^{*}+\mathrm{N}^{+} \rightarrow \mathrm{N}$ & $3.5 \times 10^{-12}$ \\
\hline $\mathrm{e}^{*}+\mathrm{NO}^{+} \rightarrow \mathrm{NO}$ & $4.0 \times 10^{-12}$ \\
\hline $\mathrm{N}^{+}+\mathrm{NO} \rightarrow \mathrm{NO}^{+}+\mathrm{N}$ & $5.1 \times 10^{-10}$ \\
\hline $\mathrm{N}^{+}+\mathrm{NO}_{2} \rightarrow \mathrm{NO}^{+}+\mathrm{NO}$ & $5.0 \times 10^{-10}$ \\
\hline $\mathrm{N}_{2}^{+}+\mathrm{O}_{2} \rightarrow \mathrm{NO}^{+}+\mathrm{NO}$ & $1.0 \times 10^{-17}$ \\
\hline $\mathrm{N}_{2}^{+}+\mathrm{NO} \rightarrow \mathrm{NO}^{+}+\mathrm{N}_{2}$ & $3.3 \times 10^{-10}$ \\
\hline $\mathrm{N}+\mathrm{NO} \rightarrow \mathrm{N}_{2}+\mathrm{O}\left({ }^{3} \mathrm{P}\right)$ & $3.0 \times 10^{-11}$ \\
\hline $\mathrm{N}+\mathrm{NO}_{2} \rightarrow 2 \mathrm{NO}$ & $6.0 \times 10^{-13}$ \\
\hline $\mathrm{N}+\mathrm{O}_{2} \rightarrow \mathrm{NO}+\mathrm{O}\left({ }^{3} \mathrm{P}\right)$ & $8.9 \times 10^{-17}$ \\
\hline $\mathrm{N}_{2}(\mathrm{~A})+\mathrm{O}\left({ }^{3} \mathrm{P}\right) \rightarrow \mathrm{NO}+\mathrm{N}\left({ }^{2} \mathrm{D}\right)$ & $7.0 \times 10^{-12}$ \\
\hline $\mathrm{N}_{2}(\mathrm{~A})+\mathrm{N}_{2}(\mathrm{~A}) \rightarrow \mathrm{N}_{2}+\mathrm{N}_{2}(\mathrm{C})$ & $1.6 \times 10^{-10}$ \\
\hline $\mathrm{N}_{2}(\mathrm{~A})+\mathrm{O}\left({ }^{3} \mathrm{P}\right) \rightarrow \mathrm{N}_{2}+\mathrm{O}\left({ }^{1} \mathrm{D}\right)$ & $2.1 \times 10^{-11}$ \\
\hline $\mathrm{O}\left({ }^{1} \mathrm{D}\right)+\mathrm{O}_{2} \rightarrow \mathrm{O}\left({ }^{3} \mathrm{P}\right)+\mathrm{O}_{2}$ & $8.0 \times 10^{-12}$ \\
\hline $\mathrm{O}\left({ }^{3} \mathrm{P}\right)+\mathrm{O}\left({ }^{3} \mathrm{P}\right)+\mathrm{N}_{2} \rightarrow \mathrm{O}_{2}+\mathrm{N}_{2}$ & $3.0 \times 10^{-33^{*}}$ \\
\hline $\mathrm{N}_{2}(\mathrm{~B})+\mathrm{N}_{2} \rightarrow \mathrm{N}_{2}(\mathrm{~A})+\mathrm{N}_{2}$ & $3.0 \times 10^{-11}$ \\
\hline $\mathrm{N}_{2}(\mathrm{~B})+\mathrm{NO} \rightarrow \mathrm{N}_{2}(\mathrm{~A})+\mathrm{NO}$ & $2.4 \times 10^{-10}$ \\
\hline $\mathrm{N}_{2}(\mathrm{C})+\mathrm{N}_{2} \rightarrow \mathrm{N}_{2}(\mathrm{~B})+\mathrm{N}_{2}$ & $1.0 \times 10^{-11}$ \\
\hline $\mathrm{N}\left({ }^{2} \mathrm{D}\right)+\mathrm{O}_{2} \rightarrow \mathrm{NO}+\mathrm{O}\left({ }^{3} \mathrm{P}\right)$ & $1.5 \times 10^{-12}$ \\
\hline $\mathrm{N}\left({ }^{2} \mathrm{D}\right)+\mathrm{N}_{2} \rightarrow \mathrm{N}+\mathrm{N}_{2}$ & $6.0 \times 10^{-15}$ \\
\hline $\mathrm{O}\left({ }^{1} \mathrm{D}\right)+\mathrm{N}_{2} \rightarrow \mathrm{O}\left({ }^{3} \mathrm{P}\right)+\mathrm{N}_{2}$ & $2.6 \times 10^{-11}$ \\
\hline
\end{tabular}

${ }^{*}$ Its unit is $\mathrm{cm}^{6} \mathrm{~s}^{-1}$. 


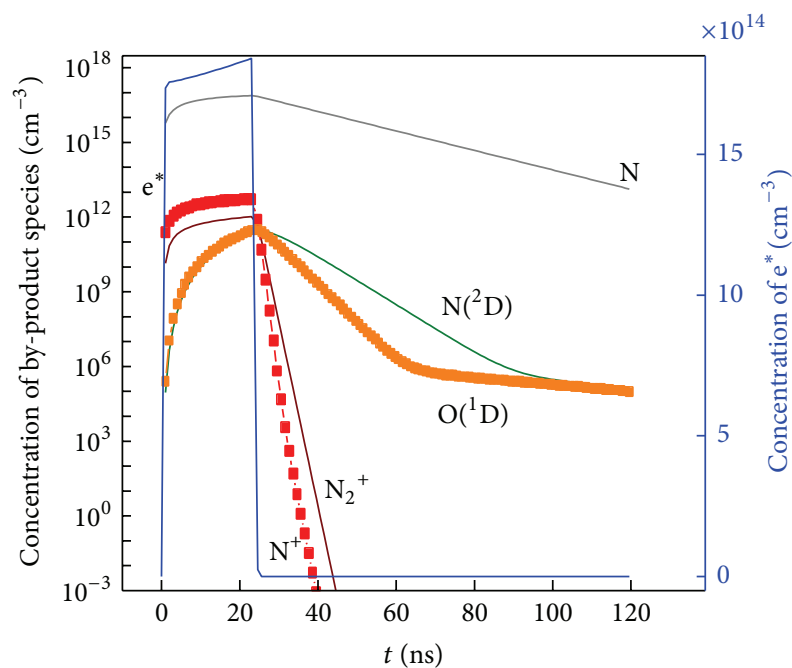

(a)

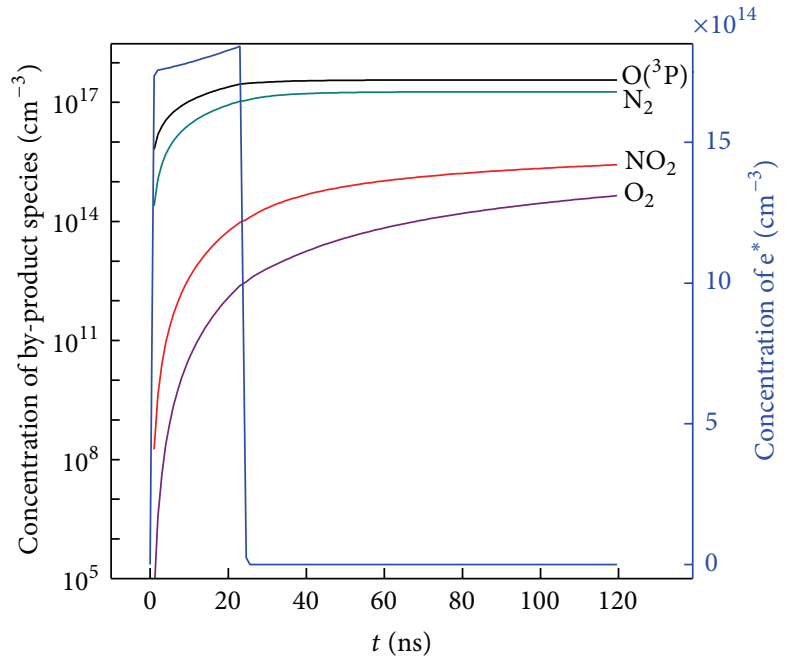

(b)

Figure 8: Concentration variance of by-product species and electrons versus time. (a) $\mathrm{N}^{+}, \mathrm{N}_{2}^{+}, \mathrm{O}\left({ }^{1} \mathrm{D}\right), \mathrm{N}\left({ }^{2} \mathrm{D}\right), \mathrm{N}$, and electron; (b) $\mathrm{O}\left({ }^{3} \mathrm{P}\right)$, $\mathrm{N}_{2}, \mathrm{O}_{2}, \mathrm{NO}_{2}$, and electron.

Figure 8(a), while other species including $\mathrm{O}\left({ }^{3} \mathrm{P}\right), \mathrm{N}_{2}$, and $\mathrm{O}_{2}$ as well as $\mathrm{NO}_{2}$ show an increasing trend of concentration in Figure 8(b). According to the law of conservation of matter, the generation of $\mathrm{O}\left({ }^{3} \mathrm{P}\right), \mathrm{N}_{2}, \mathrm{O}_{2}$, and $\mathrm{NO}_{2}$ should be derived from the consumption of $\mathrm{N}, \mathrm{N}\left({ }^{2} \mathrm{D}\right), \mathrm{N}_{2}^{+}, \mathrm{N}^{+}$, and $\mathrm{O}\left({ }^{1} \mathrm{D}\right)$. Also, it should take the different concentration magnitude order of all the species into consideration.

(1) Role of $\mathrm{O}\left({ }^{3} \mathrm{P}\right)$ for NO Removal. During discharge, large amount of $\mathrm{O}\left({ }^{3} \mathrm{P}\right)$ atoms have been accumulated. At $24.5 \mathrm{~ns}$, the atom $\mathrm{O}\left({ }^{3} \mathrm{P}\right)$ concentration of $2.9648 \times 10^{17} / \mathrm{cm}^{3}$ is higher than $\mathrm{O}\left({ }^{1} \mathrm{D}\right)$ of $3.0111 \times 10^{11} / \mathrm{cm}^{3}$ with $10^{6}$ magnitude order. $\mathrm{O}\left({ }^{3} \mathrm{P}\right)$ has obviously played the major role in oxidizing $\mathrm{NO}$ to higher oxides. As consequence, the concentration increase of $\mathrm{NO}_{2}$ from $1.1101 \times 10^{14} / \mathrm{cm}^{3}$ at $24.5 \mathrm{~ns}$ to final $2.6668 \times$ $10^{15} / \mathrm{cm}^{3}$ has been mainly ascribed to the oxidation reaction between $\mathrm{O}\left({ }^{3} \mathrm{P}\right)$ and $\mathrm{NO}$. Such oxidation reaction is ruled by

$$
\begin{array}{r}
\mathrm{O}\left({ }^{3} \mathrm{P}\right)+\mathrm{NO}+\mathrm{N}_{2} \longrightarrow \mathrm{NO}_{2}+\mathrm{N}_{2} ; \\
k=1.0 \times 10^{-31} \mathrm{~cm}^{6} \mathrm{~s}^{-1} .
\end{array}
$$

But when it comes to the low magnitude order $10^{15} / \mathrm{cm}^{3}$ of $\mathrm{NO}_{2}$ produced after discharge, it can be deduced that there is a relatively small contribution of the oxidation reaction for the total $10^{16} / \mathrm{cm}^{3} \mathrm{NO}$ removal after discharge from 5.0731 $\times 10^{18} / \mathrm{cm}^{3}$ at $24.5 \mathrm{~ns}$ to final $4.9999 \times 10^{18} / \mathrm{cm}^{3}$ as shown in Figure 7 .

There also has been $\mathrm{O}_{2}$ of $4.4522 \times 10^{14} / \mathrm{cm}^{3}$ generated at $120 \mathrm{~ns}$, which is obviously generated by bimolecular reactions between $\mathrm{O}\left({ }^{3} \mathrm{P}\right)$ atoms. But its concentration is relatively low and can be considered as neglectable reaction routine for $\mathrm{NO}$ removal.

(2) Role of N Atoms for NO Removal. Main part consumption of $\mathrm{NO}$ after discharge should be ascribed to generation of $\mathrm{N}_{2}$.

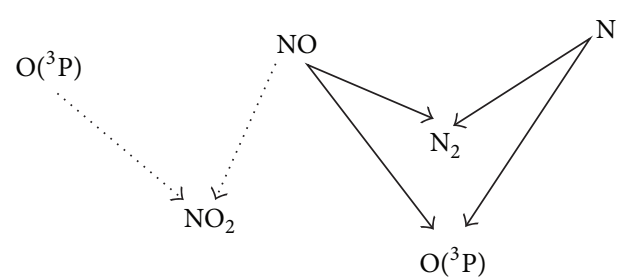

FIGURE 9: Diagram of main reaction paths for NO removal after discharge, including $\mathrm{NO}$ substituted by $\mathrm{N}$ as major reaction path (solid line) and $\mathrm{NO}$ oxidized by $\mathrm{O}\left({ }^{3} \mathrm{P}\right)$ as minor reaction path (dotted line).

For NO, the concentration decrease is in $10^{16} / \mathrm{cm}^{3}$ magnitude order. For $\mathrm{N}_{2}$, the concentration increase is also in the same $10^{16} / \mathrm{cm}^{3}$ orders from $1.1301 \times 10^{17} / \mathrm{cm}^{3}$ at $24.5 \mathrm{~ns}$ to 1.8356 $\times 10^{17} / \mathrm{cm}^{3}$. In Figure 8(a), it can also be observed that the $\mathrm{N}$ atom of $7.0503 \times 10^{16} / \mathrm{cm}^{3}$ at $24.5 \mathrm{~ns}$ which decreased to final $1.3421 \times 10^{13} / \mathrm{cm}^{3}$ has shared the key reaction routine with $\mathrm{NO}$ to generate $\mathrm{N}_{2}$ after discharge. The $\mathrm{N}$ atoms have chemically substituted $\mathrm{NO}$ to produce $\mathrm{N}_{2}$ and $\mathrm{O}\left({ }^{3} \mathrm{P}\right)$ through the following reaction:

$$
\mathrm{N}+\mathrm{NO} \longrightarrow \mathrm{N}_{2}+\mathrm{O}\left({ }^{3} \mathrm{P}\right) ; \quad k=3.0 \times 10^{-11} \mathrm{~cm}^{3} \mathrm{~s}^{-1}
$$

From the viewpoint of concentration magnitude, other species such as $\mathrm{N}\left({ }^{2} \mathrm{D}\right), \mathrm{N}_{2}{ }^{+}$, and $\mathrm{N}^{+}$have little effect on $\mathrm{NO}$ removal after discharge.

Based on the above NO removal simulation after discharge, the $\mathrm{N}$ atoms in Reaction (7) are very effective in substituting NO, while the Reaction $(6)$ of $\mathrm{O}\left({ }^{3} \mathrm{P}\right)$ atoms make a relatively small contribution by oxidizing NO. The main reaction paths and chemical species for NO removal after discharge are concluded in Figure 9. 


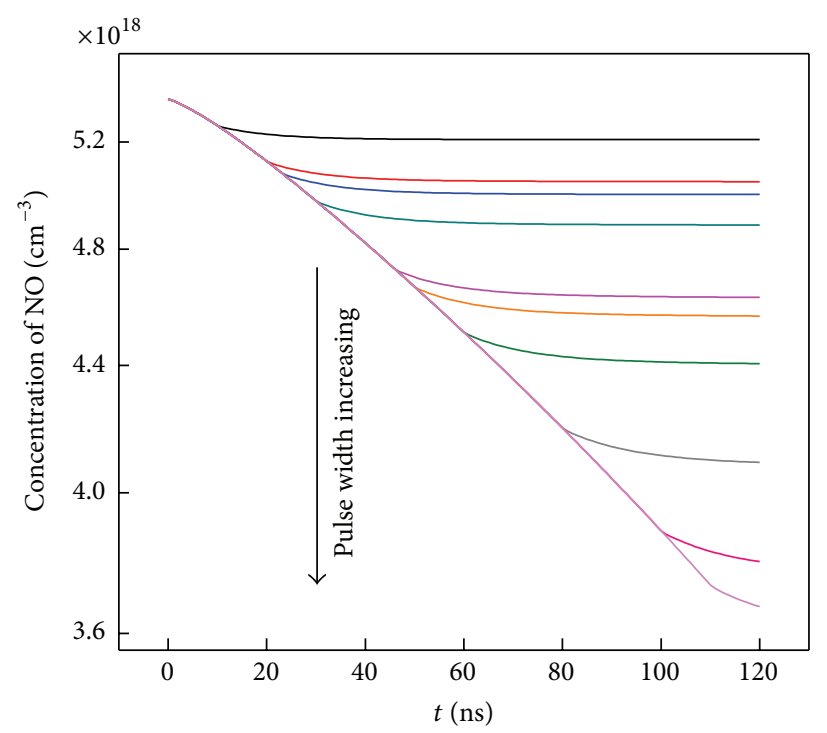

(a)

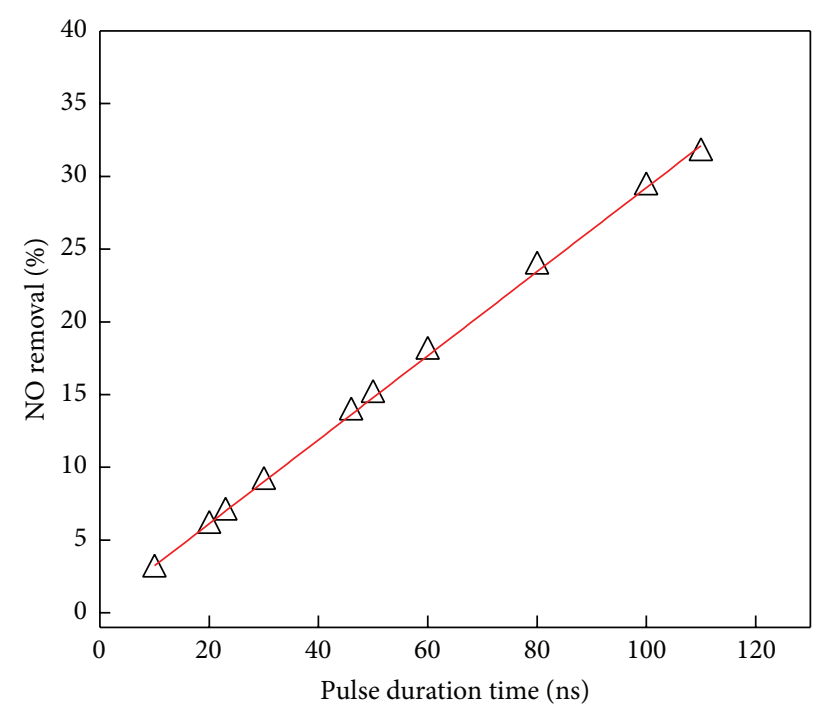

(b)

FIgURE 10: (a) NO concentration and (b) NO removal percentage achieved by adjusting pulse discharge duration width.

\subsection{Approaches for Improving the NO Removal Efficiency}

(1) Effect of Discharge Pulse Duration Width on NO Removal Efficiency. Since the species of $\mathrm{N}$ and $\mathrm{O}\left({ }^{3} \mathrm{P}\right)$ atoms are both produced by electron impact dissociation of $\mathrm{NO}$, the electron concentration has decided the dissociation rate of NO during discharge and has also affected the subsequent reactions between $\mathrm{NO}$ and the by-products during and after discharge.

Adjustment of pulse discharge width can influence the electron accumulated concentration. In Figure 10(a), the pulse duration width is varied from 10 to $110 \mathrm{~ns}$. The final NO concentrations are monotonically decreased with pulse width increasing.

Quantitatively, NO removal extent is calculated as

$$
\eta=\frac{n[\mathrm{NO}]_{t=0 \mathrm{~ns}}-n[\mathrm{NO}]_{t=120 \mathrm{~ns}}}{n[\mathrm{NO}]_{t=0 \mathrm{~ns}}} \times 100 \% .
$$

Linear increasing trend of NO removal extent has been presented in Figure 10(b); even 32\% removal percentage is achieved at pulse duration of $110 \mathrm{~ns}$. It is obvious that the electron concentration during discharge is accumulated with such a principle that its concentration is proportional to pulse duration width; the linear trend means that the NO removal efficiency is proportionally decided by the electron concentration in this simulation model. It also implies that the mechanism of NO removal during and after discharge is unchanged, though the inputted electron concentrations are different when pulse duration width varied.

(2) Effect of $\mathrm{N}_{2}$ Additive on NO Removal Efficiency. Based on the above analysis, the cost of NO removal is the discharge energy consumption with direct proportion principle. Then a question is brought out to find methods for more efficiently removing NO with less consumed discharge energy. Since the by-product species of $\mathrm{N}$ and $\mathrm{O}$ have played important roles on NO removal as shown in Figure 9, one practicable way is proposed to adjust gas ingredient in order to modify the reaction directions during and after discharge.

In Figure 11(a), the $\mathrm{N}_{2}$ gas is mixed with NO. With $\mathrm{N}_{2}$ initial concentration increased, the NO concentration at $24.5 \mathrm{~ns}$ is heightened. It implies that the electron-collision dissociation reaction of $\mathrm{NO}$ has been weakened by increasing the $\mathrm{N}_{2}$ concentration. But the final $\mathrm{NO}$ removal percentage at 120 ns shows a trend as increasing first and then decreasing in Figure 11(b). The removal efficiency has been improved with mixed relatively low concentration of $\mathrm{N}_{2}$ and deteriorated by high concentration of $\mathrm{N}_{2}$ mixed.

In Figure 11(b), the highest removal extent is $7.52 \%$ at $\mathrm{N}_{2} / \mathrm{NO}$ ratio of $2: 1$, compared with $7.11 \%$ of no $\mathrm{N}_{2}$ mixed. When more $\mathrm{N}_{2}$ inputted, the removal extent is monotone decreased and even occurred as $5.44 \%$ at $\mathrm{N}_{2} / \mathrm{NO}$ ratio of $15: 1$. Such result shows that the by-products have affected or even improved the reaction dynamic after discharge, though electron collision dissociation of NO during discharge have been weakened when $\mathrm{N}_{2}$ mixed.

In order to clarify the improving mechanism by mixed $\mathrm{N}_{2}$, the final concentration variance $\Delta$ of the main species under different $\mathrm{N}_{2} / \mathrm{NO}$ ratio is shown in Figure 12. By defining $n^{i}$ as the concentration of $i$ th species, the $\Delta_{i}$ is defined as

$$
\Delta_{i}=n_{t=0 \mathrm{~ns}}^{i}-n_{t=120 \mathrm{~ns}}^{i}
$$

In Figure 12, the removal variance of $\mathrm{NO}$ is accompanied with the generation variance of $\mathrm{N}_{2}$ and $\mathrm{NO}_{2}$ as well as $\mathrm{O}\left({ }^{3} \mathrm{P}\right)$ and varied in same magnitude order. With $\mathrm{N}_{2} / \mathrm{NO}$ ratio increased, the final generation concentrations of $\mathrm{N}_{2}$ and $\mathrm{O}\left({ }^{3} \mathrm{P}\right)$ are monotonically decreased, while that of $\mathrm{NO}_{2}$ is first increasing and then decreasing. Variance of other species such as $\mathrm{NO}^{+}, \mathrm{O}_{2}$, and $\mathrm{N}$ can be neglected. 


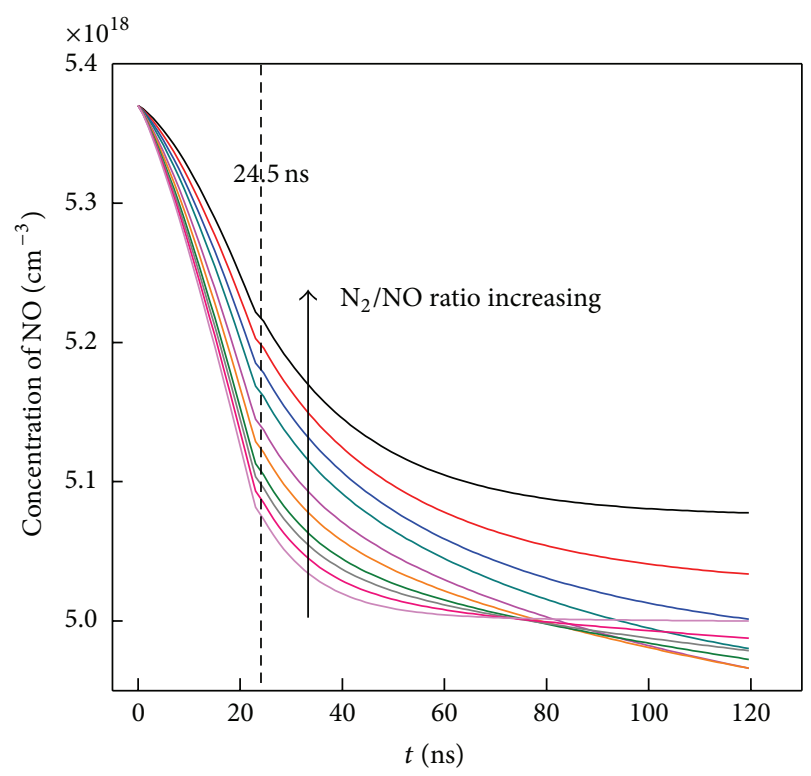

(a)

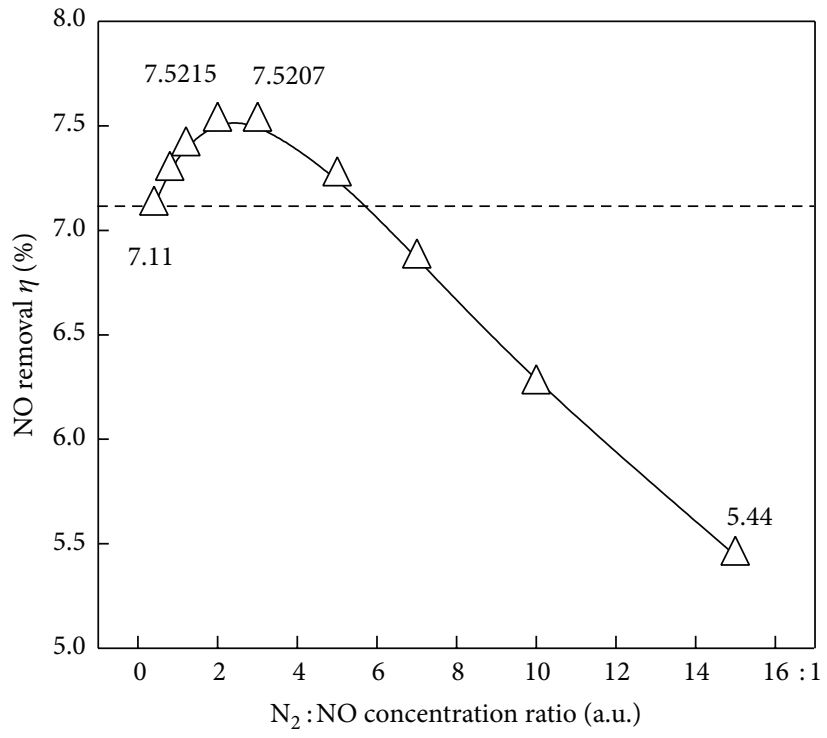

(b)

FIGURE 11: (a) The time evolution of $\mathrm{NO}$ concentration under different $\mathrm{NO} / \mathrm{N}_{2}$ ratio; (b) NO removal percentage under different $\mathrm{NO} / \mathrm{N}_{2}$ ratio.

It is obvious that the higher the $\mathrm{N}_{2} / \mathrm{NO}$ concentration ratio is, the less the electrons are consumed by NO due to the decreased collision probability. Consequently, the concentration of $\mathrm{N}$ and $\mathrm{O}\left({ }^{3} \mathrm{P}\right)$ atoms dissociated from $\mathrm{NO}$ as ruled in Reaction (10) would be decreased. Consider

$$
\mathrm{e}^{*}+\mathrm{NO} \longrightarrow \mathrm{N}+\mathrm{O}\left({ }^{3} \mathrm{P}\right)+\mathrm{e} ; \quad k=8.5 \times 10^{-10} \mathrm{~cm}^{3} \mathrm{~s}^{-1} .
$$

But there is also a compensative path for $\mathrm{N}$ atom loss according to Reaction (11) by electron collision on the $\mathrm{N}_{2}$ molecules:

$$
\mathrm{e}^{*}+\mathrm{N}_{2} \longrightarrow \mathrm{N}+\mathrm{N}+\mathrm{e} ; \quad k=2.0 \times 10^{-11} \mathrm{~cm}^{3} \mathrm{~s}^{-1} .
$$

The two reactions are competitive with each other for consuming electrons, during which the dissociation energy of $\mathrm{NO}$ is found to be smaller than that of $\mathrm{N}_{2}$. For the former, the dissociation energy of N-O bond is $6.496 \mathrm{eV}$. For the latter, the $\mathrm{N}-\mathrm{N}$ bond is dissociated at $9.76 \mathrm{eV}[48]$. As a result, the reaction rate coefficients are different, and the $\mathrm{N}_{2}$ dissociation rate coefficient of $2.0 \times 10^{-11} \mathrm{~cm}^{3} \mathrm{~s}^{-1}$ is lower at the magnitude order of $10^{-1}$ than $8.5 \times 10^{-10} \mathrm{~cm}^{3} \mathrm{~s}^{-1}$ of NO. The $\mathrm{N}$ and $\mathrm{O}\left({ }^{3} \mathrm{P}\right)$ atom concentrations are predicted to present a decreasing trend though more $\mathrm{N}_{2}$ mixed at higher $\mathrm{N}_{2} / \mathrm{NO}$ ratio.

This phenomenon is verified based on the time-evolution of main species' concentrations in Figure 13. With more $\mathrm{N}_{2}$ mixed, the $\mathrm{N}$ concentration at $24.5 \mathrm{~ns}$ is monotonically decreased in Figure 13(a). For the $\mathrm{O}\left({ }^{3} \mathrm{P}\right)$ atoms, its concentration is also decreased in Figure 13(b).

Also in Figure $13(\mathrm{~b}), \mathrm{O}\left({ }^{3} \mathrm{P}\right)$ accumulating process has presented longer time than the discharge width of $24.5 \mathrm{~ns}$. With $\mathrm{N}_{2} / \mathrm{NO}$ ratio increased, the accumulating process has been shortened. The reason is that the $\mathrm{O}\left({ }^{3} \mathrm{P}\right)$ is not only derived from the electron collision dissociation in Reaction

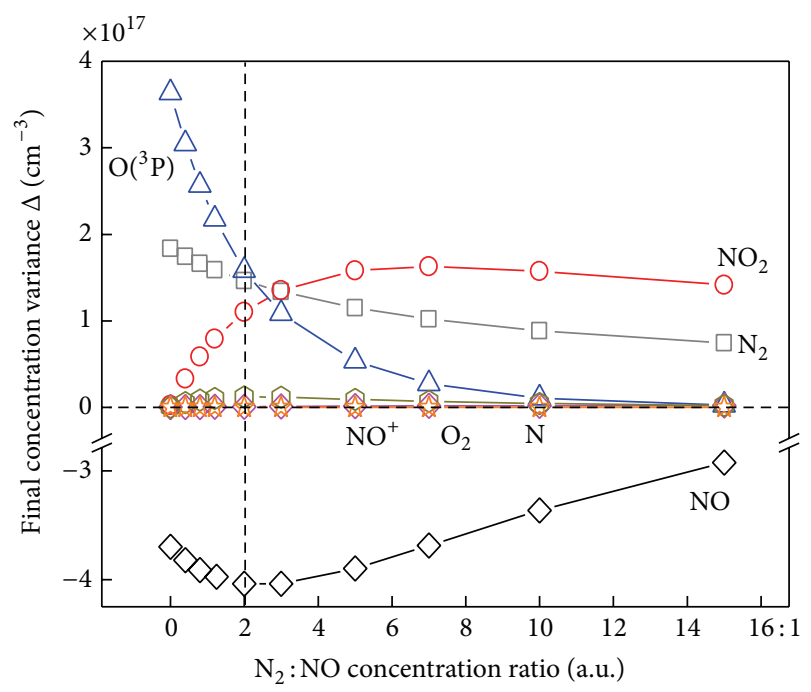

FIgURE 12: The final concentration variance $\Delta$ of the main species under different $\mathrm{N}_{2} / \mathrm{NO}$ ratio.

(10) during discharge, but can also be generated from Reaction (12) as

$$
\mathrm{N}+\mathrm{NO} \longrightarrow \mathrm{N}_{2}+\mathrm{O}\left({ }^{3} \mathrm{P}\right) ; \quad k=3.0 \times 10^{-11} \mathrm{~cm}^{3} \mathrm{~s}^{-1} .
$$

Since the $\mathrm{N}$ atom concentration generated during discharge has been weakened by increasing $\mathrm{N}_{2} / \mathrm{NO}$ ratio, the Reaction (12) for further generating $\mathrm{O}\left({ }^{3} \mathrm{P}\right)$ between $\mathrm{N}$ and $\mathrm{NO}$ has sequently been weakened. Reaction (10) during discharge has played more and more important roles for $\mathrm{O}\left({ }^{3} \mathrm{P}\right)$ generation; therefore, the accumulating process presents a shorter time at higher $\mathrm{N}_{2} / \mathrm{NO}$ ratio in Figure 13(b). As another result, the generated $\mathrm{N}_{2}$ concentration, which operated according 


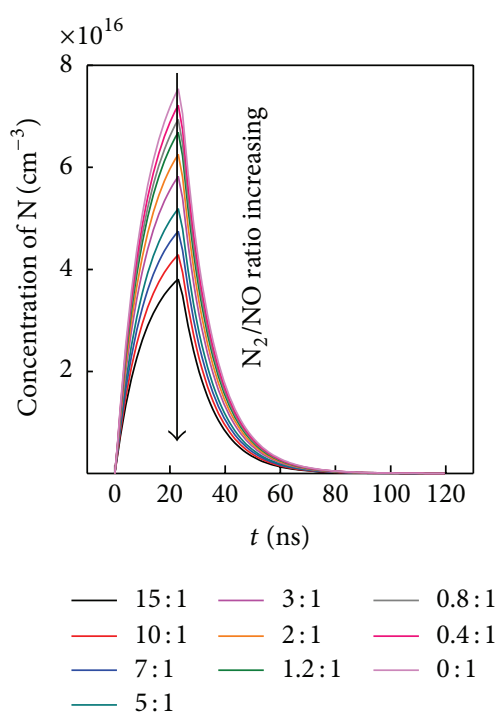

(a)

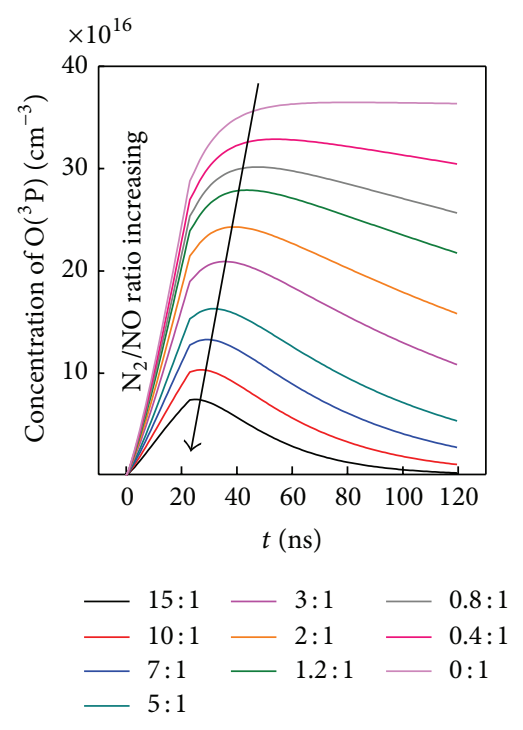

(b)

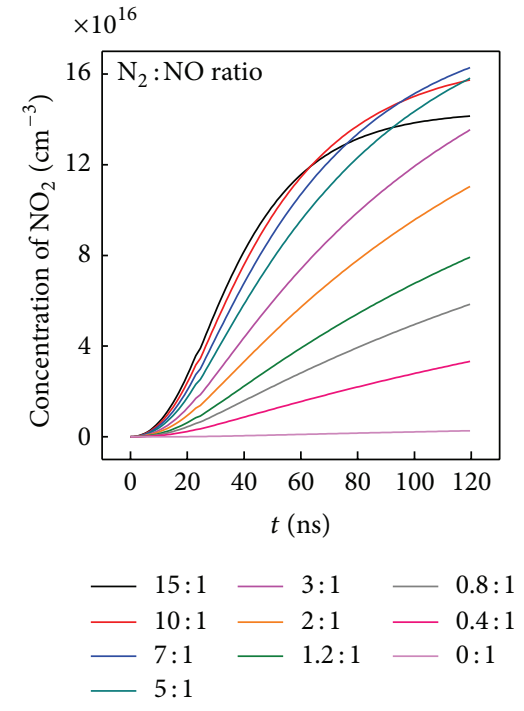

(c)

FIGURE 13: Concentration evolution versus time of (a) $\mathrm{N}$ atoms, (b) $\mathrm{O}\left({ }^{3} \mathrm{P}\right.$ ) atoms, and (c) $\mathrm{NO}_{2}$ molecules under different $\mathrm{N}_{2} / \mathrm{NO}$ mixing ratio. The arrow direction represents the $\mathrm{N}_{2} / \mathrm{NO}$ mixing ratio increase.

to the Reaction (12), has also been attenuated. Consequently, concentrations of the generated $\mathrm{N}_{2}$ and $\mathrm{O}\left({ }^{3} \mathrm{P}\right)$ both have shown monotonically decreasing trends in Figure 12.

When it comes to $\mathrm{NO}_{2}$, the $\mathrm{NO}_{2}$ yielded from Reaction (13) is determined by $\mathrm{O}\left({ }^{3} \mathrm{P}\right)$ and $\mathrm{N}_{2}$ :

$$
\begin{array}{r}
\mathrm{O}\left({ }^{3} \mathrm{P}\right)+\mathrm{NO}+\mathrm{N}_{2} \longrightarrow \mathrm{NO}_{2}+\mathrm{N}_{2} \\
k=1.0 \times 10^{-31} \mathrm{~cm}^{3} \mathrm{~s}^{-1} .
\end{array}
$$

Raising reactant concentrations usually makes the reaction operates at a higher rate by increasing collision probability per unit time. More $\mathrm{N}_{2}$ additive has accelerated Reaction (13) for oxidizing $\mathrm{NO}$ into more $\mathrm{NO}_{2}$. With $\mathrm{N}_{2} / \mathrm{NO}$ mixing ratio increased, the formation of $\mathrm{NO}_{2}$ is achieved to be maximal at $\mathrm{N}_{2} / \mathrm{NO}$ of $8: 1$. When too more $\mathrm{N}_{2}$ molecules are inputted, the $\mathrm{O}\left({ }^{3} \mathrm{P}\right)$ atom concentration is remarkably decreased according to the above analysis; then the Reaction (13) becomes slow. As shown in Figure 13(c), $\mathrm{NO}_{2}$ concentration is decreased when too more $\mathrm{N}_{2}$ are inputted at the $\mathrm{N}_{2}$ /NO ratio of $10: 1$ and $15: 1$.

Overall, the NO removal is decided by the electron collision dissociation during discharge and the substitution reaction or oxidation process during and after discharge. The optimal $\mathrm{N}_{2} / \mathrm{NO}$ mixing ratio is $2: 1$. In such a ratio, the total generated $\mathrm{O} / \mathrm{N}_{2} / \mathrm{NO}_{2}$ concentration is maximum, which can not only compensate the disadvantage of competitive electron consumption by the added $\mathrm{N}_{2}$ during discharge as shown in Figure 11(a) but also heighten the total removal percentage in Figure 11(b). By mixing $\mathrm{N}_{2}$ gas at appropriate concentration ratio, the NO removal process has been more efficiently achieved, without depositing additional discharge energy.

The optimal condition of pulsed-discharged plasma technique for NO pollutant gas removal has been quantitatively obtained in this paper through the numerical simulation method. Such results can be applied for NO gas remediation in power plants, automobile exhaust treatment, and so on.

\section{Conclusion}

This paper discusses the NO removal mechanism in pulsedischarged plasma. Emission spectra diagnosis indicates that the $\mathrm{NO}$ has transformed into $\mathrm{O}, \mathrm{N}, \mathrm{N}_{2}, \mathrm{NO}_{2}$, and other by-products, and the higher the discharge voltage is, the more the NO removed is. The plasma electron temperature $T_{\mathrm{e}}$ is deduced as $9500 \mathrm{~K}$ at voltage of $4.8 \mathrm{kV}$ inputted. The chemical reaction activation of the species has been heightened in such high $T_{\mathrm{e}}$. In order to clarify the complicated NO removal dynamic process, zero-dimensional numerical simulation indicates that the main reaction paths during pulsed discharge are the electron collision dissociation of $\mathrm{NO}$ into $\mathrm{N}$ and $\mathrm{O}$ atoms, and followed single substitution of $\mathrm{N}$ on $\mathrm{NO}$ to form $\mathrm{N}_{2}$. After discharge, the single substitution between $\mathrm{N}$ and $\mathrm{NO}$ to form $\mathrm{N}_{2}$ also plays the major role, compared with the $\mathrm{NO}_{2}$ formation by oxidizing $\mathrm{NO}$. This model also implies that the NO removal mechanism is almost the same when pulse discharge with different duration width is operated.

Furthermore, the dynamic model gives particular notice on the $\mathrm{N}_{2}$ additive for improving $\mathrm{NO}$ removal efficiency. With the $\mathrm{N}_{2} / \mathrm{NO}$ ratio increased, the maximum concentration of $\mathrm{NO}_{2}$ is achieved at ratio of $8: 1$, but the $\mathrm{N}_{2}$ and $\mathrm{O}\left({ }^{3} \mathrm{P}\right)$ concentrations are decreasing remarkably due to the modified reaction directions. There has an optimal $\mathrm{N}_{2} / \mathrm{NO}$ concentration ratio as $2: 1$ to achieve the maximal $\mathrm{NO}$ removal efficiency. At such a ratio, the total generated $\mathrm{O} / \mathrm{N}_{2} / \mathrm{NO}_{2}$ concentration is maximum, which cannot only compensate the competitive electron consumption by $\mathrm{N}_{2}$ 
additive during discharge but also heighten the total removal percentage than that without $\mathrm{N}_{2}$ mixed.

Such preliminary results indicate that the nonthermal pulse-discharged plasma technique for NO pollutant gas control must necessarily include adequate additive gas, such as the $\mathrm{N}_{2}$, for low-costly improving the removal efficiency.

\section{Conflict of Interests}

The authors declare that there is no conflict of interests regarding the publication of this paper.

\section{Acknowledgments}

This work was financially supported by the National Nature Science Foundation of China no. 10875036 and the Nature Science Foundation of Hebei Province nos. A2007000131, A2010000177.

\section{References}

[1] J. A. van Aardenne, G. R. Carmichael, H. Levy, D. Streets, and L. Hordijk, "Anthropogenic $\mathrm{NO}_{x}$ emissions in Asia in the period 1990-2020," Atmospheric Environment, vol. 33, no. 4, pp. 633646,1999 .

[2] M. Iwamoto and H. Hamada, "Removal of nitrogen monoxide from exhaust gases through novel catalytic processes," Catalysis Today, vol. 10, no. 1, pp. 57-71, 1991.

[3] D. I. Stern, "Global sulfur emissions from 1850 to 2000," Chemosphere, vol. 58, no. 2, pp. 163-175, 2005.

[4] M. V. Twigg, "Progress and future challenges in controlling automotive exhaust gas emissions," Applied Catalysis B, vol. 70, no. 1-4, SI, pp. 2-15, 2007.

[5] G. J. Frost, S. A. McKeen, M. Trainer et al., "Effects of changing power plant $\mathrm{NO}_{x}$ emissions on ozone in the eastern United States: proof of concept," Journal of Geophysical Research D, vol. 111, no. D12, Article ID D12306, 2006.

[6] S. Kim, A. Heckel, S. A. McKeen et al., "Satellite-observed U.S. power plant $\mathrm{NO}_{x}$ emission reductions and their impact on air quality," Geophysical Research Letters, vol. 33, no. 22, Article ID L22812, 2006.

[7] F. Normann, K. Andersson, B. Leckner, and F. Johnsson, "Emission control of nitrogen oxides in the oxy-fuel process," Progress in Energy and Combustion Science, vol. 35, no. 5, pp. 385-397, 2009.

[8] L. Chen, J. Li, and M. Ge, "Promotional effect of ce-doped $\mathrm{V}_{2} \mathrm{O}_{5}-\mathrm{WO}_{3} / \mathrm{TiO}_{2}$ with low vanadium loadings for selective catalytic reduction of $\mathrm{NO}_{x}$ by $\mathrm{NH}_{3}$," Journal of Physical Chemistry C, vol. 113, no. 50, pp. 21177-21184, 2009.

[9] M. Takeuchi and S. Matsumoto, " $\mathrm{NO}_{x}$ storage-reduction catalysts for gasoline engines," Topics in Catalysis, vol. 28, no. 1-4, pp. 151-156, 2004.

[10] A. Keskin and A. Emiroglu, "Catalytic reduction techniques for post-combustion diesel engine exhaust emissions," Energy Education Science and Technology A, vol. 25, no. 1-2, pp. 87-103, 2010.

[11] X. Tang, X. Xu, H. Yi, C. Chen, and C. Wang, "Recent developments of electrochemical promotion of catalysis in the techniques of DeNO ${ }_{x}$," Scientific World Journal, vol. 2013, Article ID 463160, 13 pages, 2013.
[12] F. Normann, K. Andersson, B. Leckner, and F. Johnsson, "High-temperature reduction of nitrogen oxides in oxy-fuel combustion," Fuel, vol. 87, no. 17-18, pp. 3579-3585, 2008.

[13] D. Kühnemuth, F. Normann, K. Andersson, F. Johnsson, and B. Leckner, "Reburning of nitric oxide in oxy-fuel firing-the influence of combustion conditions," Energy \& Fuels, vol. 25, no. 2, pp. 624-631, 2011.

[14] Z. Liu and S. Woo, "Recent advances in catalytic DeNO science and technology," Catalysis Reviews, vol. 48, no. 1, pp. 43-89, 2006.

[15] A. Mizuno, "Industrial applications of atmospheric nonthermal plasma in environmental remediation," Plasma Physics and Controlled Fusion, vol. 49, no. 5 A, SI, pp. A1-A15, 2007.

[16] J. S. Chang, "Physics and chemistry of plasma pollution control technology," Plasma Sources Science and Technology, vol. 17, no. 4, Article ID 045004, 2008.

[17] R. Hackam and H. Akiyama, "Air pollution control by electrical discharges," IEEE Transactions on Dielectrics and Electrical Insulation, vol. 7, no. 5, pp. 654-683, 2000.

[18] T. Namihira, S. Tsukamoto, D. Wang et al., "Improvement of $\mathrm{NO}_{x}$ removal efficiency using short-width pulsed power," IEEE Transactions on Plasma Science, vol. 28, no. 2, pp. 434-442, 2000.

[19] Y. Lee, W. Jung, Y. Choi et al., "Application of pulsed corona induced plasma chemical process to an industrial incinerator," Environmental Science and Technology, vol. 37, no. 11, pp. 25632567,2003

[20] NIST Atomic Spectra Database Lines Form, http://physics.nist .gov/PhysRefData/ASD/lines_form.html.

[21] O. Eichwald, M. Yousfi, A. Hennad, and M. D. Benabdessadok, "Coupling of chemical kinetics, gas dynamics, and charged particle kinetics models for the analysis of NO reduction from flue gases," Journal of Applied Physics, vol. 82, no. 10, pp. 47814794, 1997.

[22] M. Uddi, N. Jiang, I. V. Adamovich, and W. R. Lempert, "Nitric oxide density measurements in air and air/fuel nanosecond pulse discharges by laser induced fluorescence," Journal of Physics D, vol. 42, no. 7, Article ID 075205, 2009.

[23] F. J. Gordillo-Vázquez, "Air plasma kinetics under the influence of sprites," Journal of Physics D, vol. 41, no. 23, Article ID 234016, 2008

[24] J. T. Herron and D. S. Green, "Chemical kinetics database and predictive schemes for nonthermal humid air plasma chemistry, part II: neutral species reactions," Plasma Chemistry and Plasma Processing, vol. 21, no. 3, pp. 459-481, 2001.

[25] T. Arcos, C. Domingo, V. J. Herrero, M. M. Sanz, and I. Tanarro, "Diagnostics and kinetic modeling of the ignition and the extinction transients of a hollow cathode $\mathrm{N}_{2} \mathrm{O}$ discharge," Journal of Physical Chemistry A, vol. 104, no. 17, pp. 3974-3983, 2000.

[26] M. Castillo, I. Méndez, A. M. Islyaikin, V. J. Herrero, and I. Tanarro, "Low-pressure DC air plasmas. Investigation of neutral and ion chemistry," Journal of Physical Chemistry A, vol. 109, no. 28, pp. 6255-6263, 2005.

[27] F. Leipold, A. Fateev, Y. Kusano, B. Stenum, and H. Bindslev, "Reduction of NO in the exhaust gas by reaction with N radicals," Fuel, vol. 85, no. 10-11, pp. 1383-1388, 2006.

[28] T. Wang, B. Sun, H. Xiao, D. Wang, X. Zhu, and Y. Zhong, "Effect of water vapor on NO removal in a DBD reactor at different temperatures," Plasma Chemistry and Plasma Processing, vol. 33, no. 4, pp. 681-690, 2013. 
[29] C. Tsai, H. Yang, C. G. Jou, and H. M. Lee, "Reducing nitric oxide into nitrogen via a radio-frequency discharge," Journal of Hazardous Materials, vol. 143, no. 1-2, pp. 409-414, 2007.

[30] J. L. Hueso, A. R. González-Elipe, J. Cotrino, and A. Caballero, "Plasma chemistry of NO in complex gas mixtures excited with a surfatron launcher," Journal of Physical Chemistry A, vol. 109, no. 22, pp. 4930-4938, 2005.

[31] G. Yu, Q. Yu, Y. Jiang, K. Zeng, and F. Gu, "Mechanism of NO reduction with non-thermal plasma," Journal of Environmental Sciences, vol. 17, no. 3, pp. 445-447, 2005.

[32] G. Zhang, W. Jin, and H. Zheng, "Dynamic mechanism about the fluorescence emission of NO dielectric barrier discharge plasma," Journal of Quantitative Spectroscopy and Radiative Transfer, vol. 127, pp. 90-95, 2013.

[33] T. Yumii, T. Yoshida, K. Doi, N. Kimura, and S. Hamaguchi, "Oxidation of nitric oxide by atmospheric pressure plasma in a resonant plasma reactor," Journal of Physics D, vol. 46, no. 13, Article ID 135202, 2013.

[34] H. Wedaa, M. Abdel-Salam, A. Ahmed, and A. Mizuno, "NO removal using dielectric barrier discharges in a multirod reactor stressed by AC and pulsed high voltages," IEEE Transactions on Dielectrics and Electrical Insulation, vol. 18, no. 5, pp. 1743-1751, 2011.

[35] M. A. Malik, J. F. Kolb, Y. Sun, and K. H. Schoenbach, "Comparative study of NO removal in surface-plasma and volume-plasma reactors based on pulsed corona discharges," Journal of Hazardous Materials, vol. 197, pp. 220-228, 2011.

[36] E. Böös and W. Wang, "Apparatus and method for the removal of nitrogen dioxide from a flue gas stream," US Patent, US20130259786 A1, 2012.

[37] H. Wang, X. Li, P. Chen, M. Chen, and X. Zheng, "An enhanced plasma-catalytic method for $\mathrm{DeNO}_{x}$ in simulated flue gas at room temperature," Chemical Communications, vol. 49, no. 81, pp. 9353-9355, 2013.

[38] H. Wang, Q. Yu, T. Liu, L. Xiao, and X. Zheng, " $\mathrm{NO}_{x}$ storage and reduction with methane by plasma at ambient temperature," RSC Advances, vol. 2, no. 12, pp. 5094-5097, 2012.

[39] Y. Takahara, A. Ikeda, M. Nagata, and Y. Sekine, "Lowtemperature NO decomposition in humidified condition using plasma-catalyst system," Catalysis Today, vol. 211, pp. 44-52, 2013.

[40] L. Huang and Y. Dang, "Removal of $\mathrm{SO}_{2}$ and $\mathrm{NO}_{x}$ by pulsed corona combined with in situ $\mathrm{Ca}(\mathrm{OH})_{2}$ absorption," Chinese Journal of Chemical Engineering, vol. 19, no. 3, pp. 518-522, 2011.

[41] NIST Atomic Spectra Database Lines Form, http://physics.nist .gov/PhysRefData/ASD/lines_form.html.

[42] Z. Wang, X. Zhang, Z. Zhou, W. Chen, J. Zhou, and K. Cen, "Effect of additive agents on the simultaneous absorption of $\mathrm{NO}_{2}$ and $\mathrm{SO}_{2}$ in the Calcium Sulfite slurry," Energy \& Fuels, vol. 26, no. 9, pp. 5583-5589, 2012.

[43] H. Griem, Principles of Plasma Spectroscopy (Cambridge Monographs on Plasma Physics), Cambridge University Press, 2005.

[44] J. Cooper, "Plasma spectroscopy," Reports on Progress in Physics, vol. 29, part I, pp. 35-130, 1966.

[45] G. Froment, K. Bischoff, and J. Wilde, Chemical Reactor Analysis and Design, John Wiley \& Sons, New York, NY, USA, 2011.

[46] K. Behringer and U. Fantz, "Spectroscopic diagnostics of glow discharge plasmas with non-Maxwellian electron energy distributions," Journal of Physics D, vol. 27, no. 10, pp. 2128-2135, 1994.

[47] J. Butcher, Numerical Methods for Ordinary Differential Equations, John Wiley \& Sons, New York, NY, USA, 2003.

[48] M. Brook and J. Kaplan, "Dissociation energy of NO and $\mathrm{N}_{2}$," Physical Review, vol. 96, no. 6, pp. 1540-1542, 1954. 

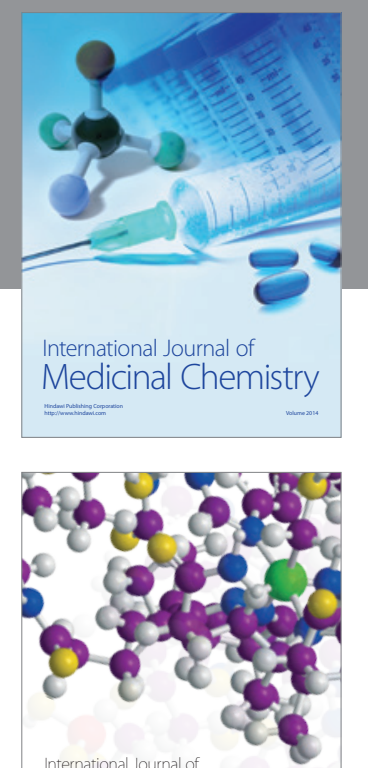

\section{Carbohydrate} Chemistry

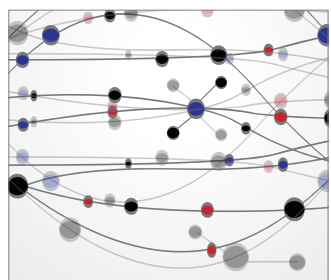

The Scientific World Journal
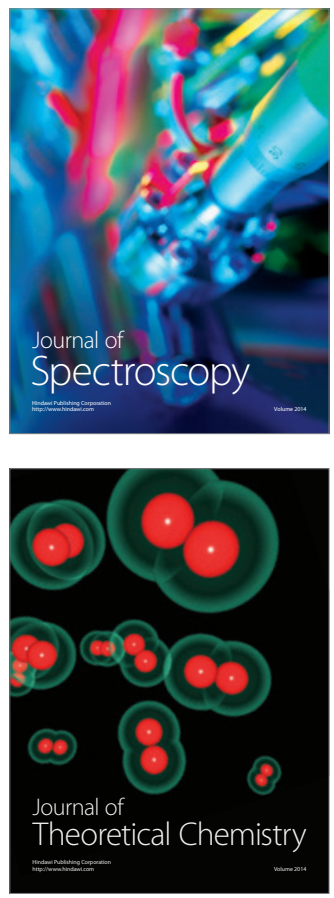
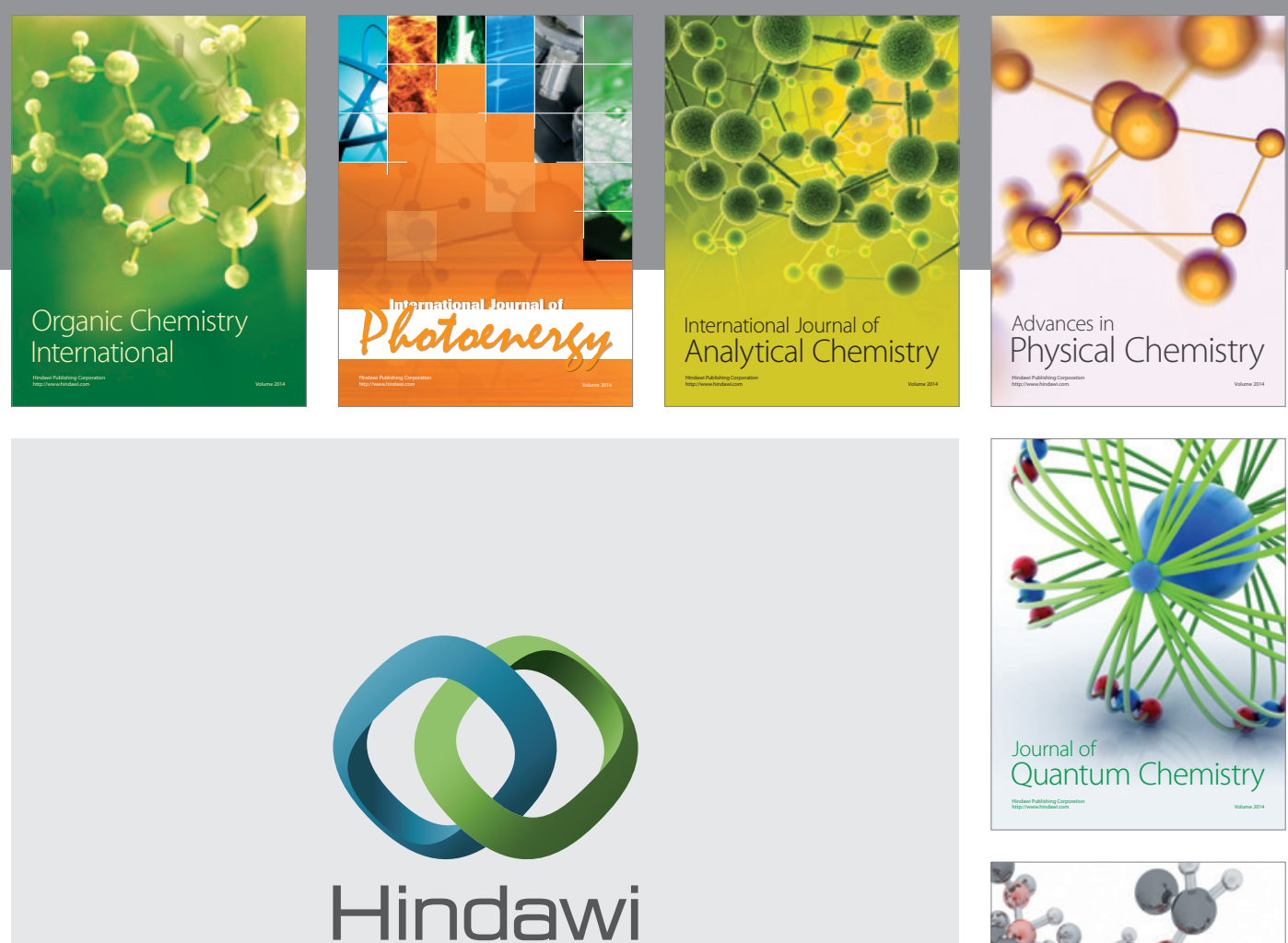

Submit your manuscripts at

http://www.hindawi.com

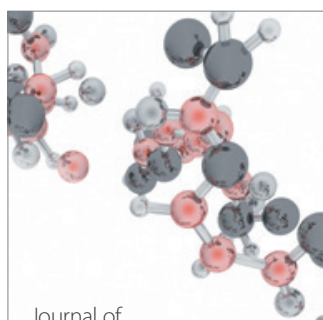

Analytical Methods

in Chemistry

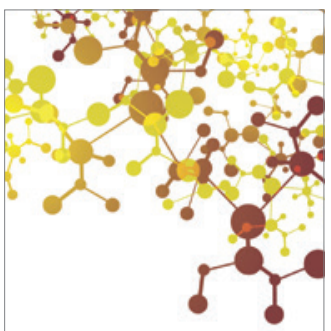

Journal of

Applied Chemistry

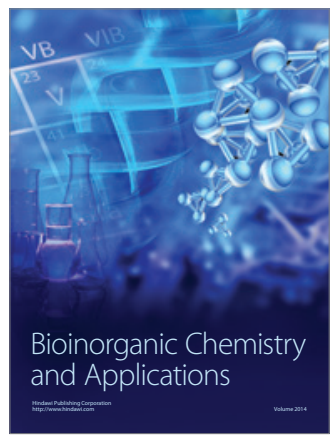

Inorganic Chemistry
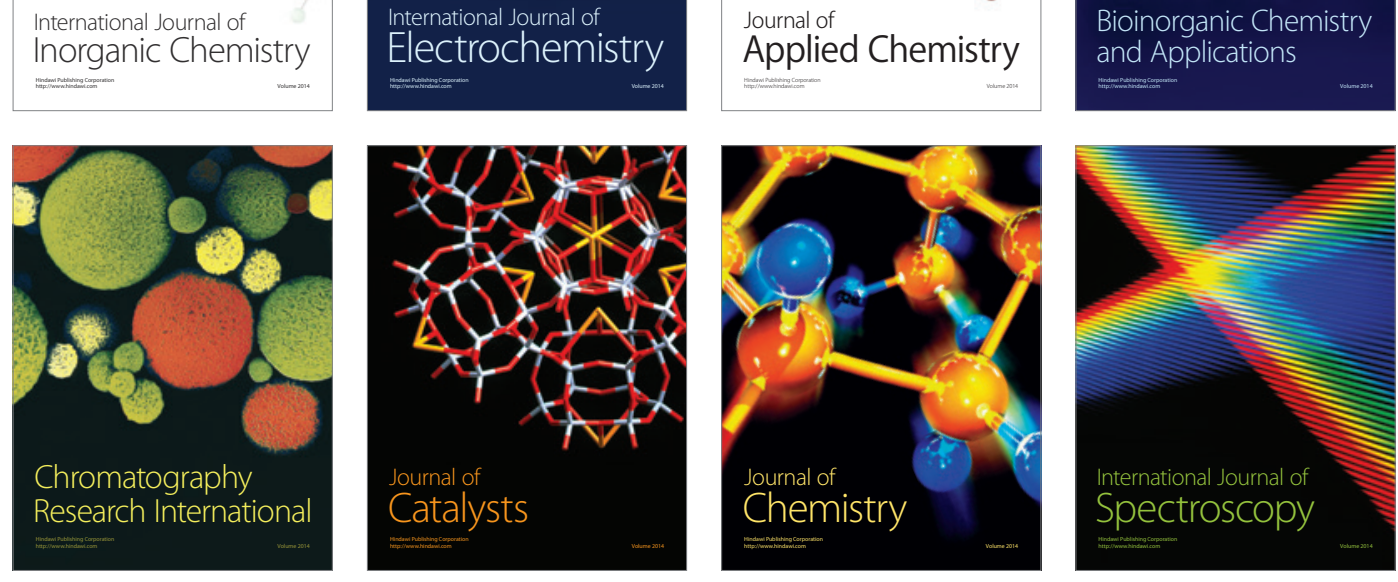